\title{
Colouring the Mediterranean: Production and Consumption of Purple-dyed Textiles in Pre-Roman Times
}

\author{
Beatriz Marín-Aguilera ${ }^{1}$, Francesco Iacono $^{2}$ and Margarita Gleba ${ }^{3}$ \\ ${ }^{1}$ McDonald Institute for Archaeological Research, University of Cambridge, Downing Street, Cambridge \\ CB2 3ER, UK \\ E-mail: bm499@cam.ac.uk \\ ${ }^{2}$ McDonald Institute for Archaeological Research, University of Cambridge, Downing Street, Cambridge \\ CB2 3ER, UK \\ E-mail: fi216@cam.ac.uk \\ ${ }^{3}$ McDonald Institute for Archaeological Research, University of Cambridge, Downing Street, Cambridge \\ CB2 3ER, UK \\ E-mail: mg704@cam.ac.uk
}

\begin{abstract}
Purple textiles were highly valued in the ancient Mediterranean as a symbol of prestige, social status and power. Despite the numerous publications focused on the production and spread of purple dye technologies, the discussion regarding this particular dye has often been compartmentalised regionally (eastern or western Mediterranean) and chronologically (second or first millennium BC). The aim of this paper is threefold: (1) to propose a full chaîne opératoire for the production of shellfish-purple-dyed textiles; (2) to synthesise the archaeological evidence on production and consumption of such textiles in the entire Mediterranean before the Romans; and (3) to discuss the social implications of the production and consumption of these textiles, to gain a better understanding of their economic and social significance.
\end{abstract}

Keywords: dyeing, textiles, Bronze Age Mediterranean, chaîne opératoire, democratisation, globalisation, Iron Age Mediterranean, shellfish-purple

\section{Introduction}

Our value perception of ancient textiles is strongly influenced by our views on contemporary fabrics, which, in turn, are based on a paradigm largely established during the Industrial Revolution, when mechanised mass production made these goods widely and cheaply available. Looking at the deep history of textiles, however, we can suggest that an equally significant 'revolution' in the way textiles were seen and valued occurred earlier in the human experience, when textiles started to serve more regularly as a means of differentiating individuals and groups within ancient societies and became part of 'prestige economies' (e.g. Soffer et al. 2000: 524). In particular, it has been argued that processes of societal differentiation and state formation have been accompanied by the production of textiles characterised by increasing added value in ways that made some products stand out from the mass of similar artefacts (McCorriston 1997; Halstead and Isakidou 2011). Time investment 
in raw materials and new technologies played a key role in this process: ancient Mediterranean societies represent an extreme example of the use of coloured textiles as status symbols (on textile value see Harris 2018), with the use of costly shellfish-based dyes an increasingly common strategy to mark societal differentiation during the Bronze Age and Iron Age (IA) in many cultures around the Mediterranean basin.

While archaeology and ancient history have long recognised the importance of shellfishpurple (on history of the studies see Haubrichs 2005), the discussion has often been compartmentalised, both regionally and chronologically, thus considerably limiting its analytical potential. Studies concerning the production of shellfish-purple dye in the second millennium BC in the Mediterranean have privileged the eastern region over the central-western Mediterranean and the question of primacy (e.g. Alberti 2006; Burke 2010; Brogan et al. 2012). For the first millennium BC, however, with Phoenician, Greek and particularly Roman expansion, it is the western Mediterranean that has been emphasised (e.g. Alfaro et al. 2004; González et al. 2017). The Mediterranean as a whole, despite being recognised as a connecting element across periods, is rarely considered (e.g. see the map in Kalaitzaki et al. 2017: 109). More importantly, the available data have never been synthesised in the attempt to reconstruct the entire chaine opératoire of shellfish-purple-dyed textiles, the focus usually falling on a specific stage only (e.g. fishing, dye extraction or dyeing); all these data are rarely combined with an exploration of the social and economic implications of the development and expansion of purple technology.

In this regard, it is important to acknowledge considerable geographic and chronological differences in economic, political and social terms between eastern, central and western Mediterranean communities. During the Bronze Age, the eastern Mediterranean was mostly dominated by highly bureaucratic and structured states characterised by medium- to large-scale economies with long-distance exchange networks extending to the central Mediterranean; by the end of the period, these states were replaced by a cluster of petty polities and city states (Voutsaki and Killen 2001; Moreno-García 2016). Large populated centres and palatial elites based their power on control of the production, distribution and trade of goods, although private initiative was also involved, especially from the twelfth century $\mathrm{BC}$ onward. In contrast, in the central and western Mediterranean during the same period, the population was distributed in small-to-medium nucleated and hierarchically organised communities where craft production was small in scale and mostly regionally connected (Cruz-Berrocal et al. 2013; Attema et al. 2016). It was only in the eighth and seventh centuries $\mathrm{BC}$ that urban centres in the central Mediterranean region became fully immersed into long-distance trade, with Phoenician and Greek expansion westwards (Osborne and Cunliffe 2005), while urbanisation in the western Mediterranean came even later, in the late sixth to fifth century BC (Bonet-Rosado and Mata-Parreño 2015; Sanmartí 2015). These differences in the socio-political development of various Mediterranean societies also influenced the production and consumption patterns of shellfish-purple-dyed textiles.

The aim of this paper is thus threefold: (1) to combine the data and various approaches to propose a chaine opératoire for the production of shellfish-purple-dyed textiles; (2) to synthesise the archaeological evidence on the production and consumption of such textiles known to date in the Mediterranean, from the Bronze Age through pre-Roman times, linking the eastern Mediterranean with the central and western regions; and (3) to discuss the social and political implications suggested by changes in production and consumption patterns across time and space. ${ }^{1}$

\section{The Evidence ${ }^{2}$}

The term 'shellfish-purple dye' is generally used to refer to a violet dye composed of several 
chemically related colourants and obtained from marine molluscs belonging to the Muricidae family; the colours range in shade from purplishred to violet-blue (Cardon 2007: 553-87 with refs.). Three species were exploited for purpledye production in the ancient Mediterranean: Hexaplex trunculus (formerly Murex trunculus), Bolinus brandaris (formerly Murex brandaris) and Stramonita haemastoma (formerly Purpura haemastoma). These species are ubiquitous in the Mediterranean Sea, with the last more common in the western region (Houart 2001).

The purple dye is not present in the living animal but is produced after its death through enzymatic hydrolysis of the colourless chemical precursors of the colourants present in the mollusc's hypobranchial gland (Cardon 2007: 554; Cooksey 2017). The chemical reactions involved in the formation of different purple colourants are complex and the resulting colour depends on the chemical precursors present in specific mollusc species, as well as on the variations in the amounts of oxygen and light that the dye is exposed to. In particular, the shade of purple depends on the presence or absence of bromine, ranging from two atoms of bromine in 6,6'-dibromoindigotin, the main colourant in violet-red purple, to the absence of bromine in blue indigotin. The former has generally been connected with the 'Tyrian purple', known as argaman in the Bible and argmn/argamannu in Ugaritic and Assyrian texts (Soriga 2017), while the latter is interpreted as the biblical tekhelet (Koren 2005). Written sources from the second millennium BC through to the Byzantine period inform us of the great variety of purple shades, with particular tones being fashionable during specific periods (e.g. Meiers 2017). However, while much work elucidating the chemical processes involved has been carried out recently, many problems of purple dyeing remain to be solved (Cooksey 2017).

The study of shellfish-purple production is based on a number of sources; alongside written sources and living molluscs, as referred to above, there is also archaeological evidence consisting of installations, tools, surviving textiles and archaeomalacological material, and also ethnographic data (these are noted by e.g. Alberti 2008; Susmann 2015; Kalaitzaki et al. 2017). These sources all have their advantages and limitations, but most importantly they refer to very different aspects of shellfish-purple-dye history: archaeological studies of workshops and experimental archaeology deal primarily with the production side, while the actual textiles provide evidence of consumption. Ancient written sources offer potential insights into both aspects. However, these diverse types of evidence are rarely combined to produce a more holistic view of the production process and its social, economic and political implications. This is largely because they are typically investigated within different disciplines, such as analytical chemistry, biology, archaeomalacology, history and archaeology. Furthermore, shellfish-purple dying is often studied in isolation from other productive activities and economic processes with which it was inextricably intertwined (but see Bernal Casasola et al. 2011); its connection with the textile production process is rarely considered in detail, if at all. Yet if we look at the ancient written sources, the value of the dye was always subsumed in the social and political value of purple textiles, and so we need to consider purple-dye production as part of the textile operational sequence, rather than an industry in its own right.

\section{Chaîne opératoire of Shellfish-purple-dyed Textiles}

The main stages of the chaîne opératoire for creating shellfish-purple-dyed textiles in the ancient Mediterranean outlined below include mollusc harvesting, possible storage, dye extraction, dyeing, textile production and consumption of the finished product. These stages, however, should be understood within the broader operational sequence of textile production that would have 


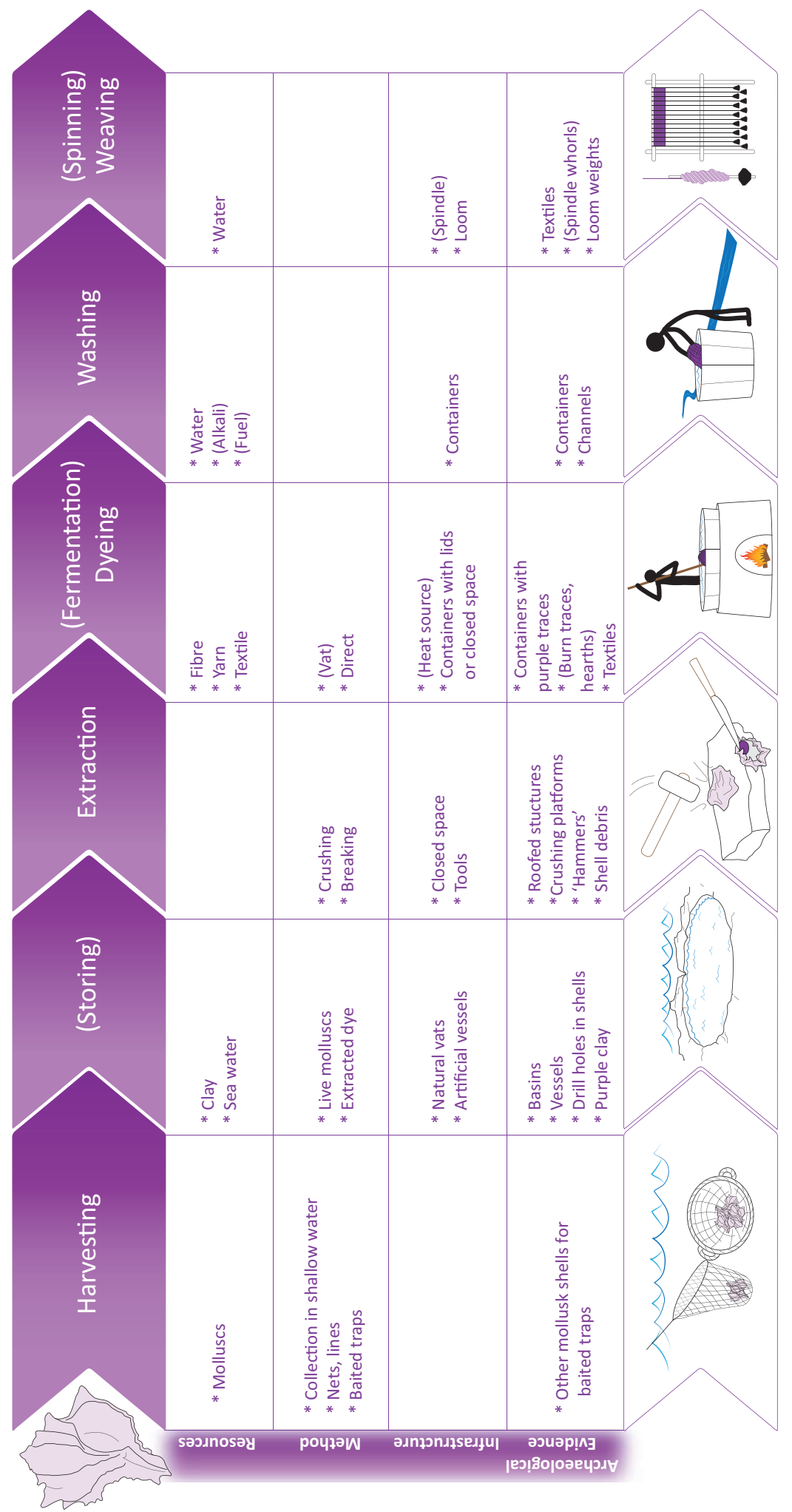

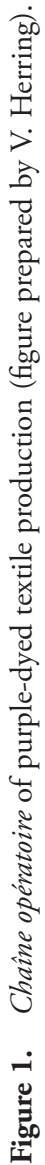




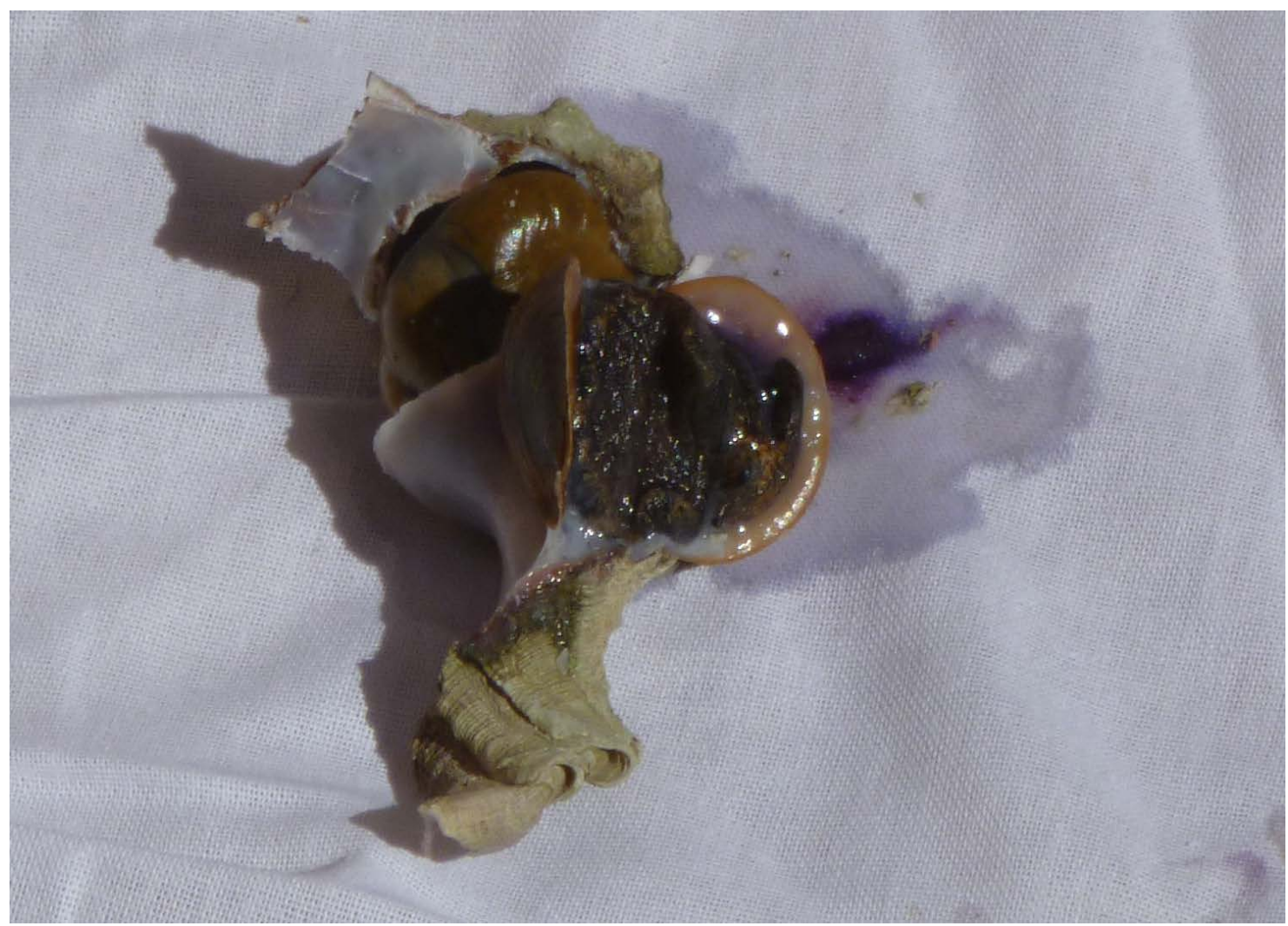

Figure 2. Hexaplex trunculus shell with hypobranchial gland exposed and purple dye on cloth, the result of direct dyeing. (M. Gleba).

included fibre procurement and processing, thread production, cloth weaving and finishing (Andersson Strand 2015). The combined sequence is presented in schematic form in Figure 1.

\section{Mollusc Harvesting}

The first step was obtaining the raw material, which involved harvesting the shellfish. Due to differences in their habitation environments, Hexaplex trunculus and Stramonita haemastoma could have been harvested by hand (Aristotle 5.15.599a.15), whereas Bolinus brandaris likely required devices such as a net, a line or a baited trap (Cardon 2007: 567-68, 578, 583; Alfaro and Mylona 2014: 154-59). Experimental work suggests that a combination of collection by diving and baited baskets may be a particularly efficient way to collect purple shellfish (Ruscillo 2005; 2006: 808-17).

\section{Storage}

The shellfish had to be fresh for purple-dye production, although there is some evidence for the snails being kept alive in seawater, either in natural or artificial installations, in order to collect sufficient numbers to assure a steady supply of raw material. Aristotle (5-15.599a.15) mentions that fishermen kept snails in baskets, while Pliny the Elder (9.60) noted that snails could be kept up to 50 days in small containers. Such practices may have been present at the island of Chryssi south of Crete, in the eighteenth through to the fifteenth century BC (Apostolakou et al. 2016: 202), as suggested by small drill holes in the shells, which are not the result of gland extraction 
but rather the outcome of cannibalism between snails (Spanier 1986: 467).

\section{Dye Extraction}

Shell debris, although providing indirect evidence for purple-dye production, is the main by-product of such production and survives well archaeologically. Interpretation of shell debris, however, has to be done with caution and careful consideration of archaeological context (Alberti 2008; Susmann 2015): the breaking of the mollusc shell to ensure the rupture of the hypobranchial gland was a crucial phase of the production process (Figure 2), and such fragmentation is one of the primary indicators used to distinguish alimentary consumption of muricid molluscs from their use for dyeing, as in the former case shells remain intact (Ruscillo 2005: 103).

Crushing requires a hard platform, such as a rock, and some type of hammer-like imple- ment, which can be as simple as a small stone. A collection of pounding stones and platforms found in Rooms 2 and 3 at Bronze Age Chryssi have been interpreted as equipment for crushing shells (Apostolakou et al. 2016: 203). At Motya, a Phoenician colony just off the west coast of Sicily dated to the sixth and fifth centuries BC, stone hammers and four sperm whale vertebrae were identified as tools for shellfish processing (Reese 2005).

In order to control the oxidising reaction that transforms the whitish transparent mucus into a purple ink-like substance, exposure to direct sunlight should be limited. It is thus likely that many of the structures devoted to this specific purpose were roofed, as suggested by the evidence from Chryssi, where both the pounding equipment and shell debris were found inside a building (Apostolakou et al. 2016).

The extensive archaeological evidence for preRoman times is synthesised in Table 1 .

Table 1. Sites with information about the production and organisation of the purple dye industry (F. Iacono and B. Marín-Aguilera). We can be sure that early traces of production in the Levantine area are underrepresented, as these will have been obliterated by later phases of production. Given space limitations, only the main or latest bibliographic references are provided here. We do not include sites where the number of shells was less than five (e.g. Tavira in Portugal, Castro Grande de Neixón in Galicia, Spain).

Abbreviations: Direct = direct evidence of production (e.g. structures or vessels with purple dye traces, purple-dyed textile fragments); Debris prim. = fragmented shell debris in primary production context; Debris redep. = fragmented shell debris redeposited in secondary context; $\mathrm{BA}=$ Bronze Age; EBA = Early Bronze Age; $\mathrm{MBA}=$ Middle Bronze Age; LBA = Late Bronze Age; EIA = Early Iron Age; Arch. = Archaic period; Class. = Classical period; Hell. = Hellenistic period.

\begin{tabular}{|c|c|c|c|c|c|}
\hline Site & Direct & $\begin{array}{l}\text { Debris } \\
\text { prim. }\end{array}$ & $\begin{array}{c}\text { Debris } \\
\text { redep }\end{array}$ & Chronology & References \\
\hline \multicolumn{6}{|l|}{ Croatia } \\
\hline Sveta Trojica & & $\mathrm{x}$ & & Hell. & Tonc and Radman-Livaja 2018 \\
\hline \multicolumn{6}{|l|}{ Cyprus } \\
\hline Pyrgos Marvoraki & $\mathrm{x}$ & $\mathrm{x}$ & & EBA-MBA & Lentini 2009: 153-71 \\
\hline Hala Sultan Tekke & & $\mathrm{x}$ & & LBA & Fischer and Bürge 2016: 37 \\
\hline Polis & & $\mathrm{x}$ & & EIA & Reese 2000 \\
\hline \multicolumn{6}{|l|}{ Greece } \\
\hline Agia Irini & & $\mathrm{x}$ & & $\mathrm{BA}$ & Carannante 2014, with refs. \\
\hline Agios Stephanos & & $\mathrm{x}$ & & $\mathrm{BA}$ & Carannante 2014, with refs. \\
\hline Eleusis & & $\mathrm{x}$ & & $\mathrm{BA}$ & Carannante 2014, with refs. \\
\hline Tylissos & & $\mathrm{x}$ & & $\mathrm{BA}$ & Reese 1987 \\
\hline
\end{tabular}




\begin{tabular}{|c|c|c|c|c|c|}
\hline Site & Direct & $\begin{array}{l}\text { Debris } \\
\text { prim. }\end{array}$ & $\begin{array}{c}\text { Debris } \\
\text { redep }\end{array}$ & Chronology & References \\
\hline Agios Kosmas & & $\mathrm{x}$ & & EBA & Reese 1987 \\
\hline Aigina & & & $\mathrm{x}$ & EBA & Reese 1987 \\
\hline Petras & & & $\mathrm{x}$ & EBA-MBA & Brogan et al. 2012 \\
\hline Myrtos & & $\mathrm{x}$ & & EBA-MBA & Stieglitz 1994 \\
\hline Sissi & & $\mathrm{x}$ & & EBA-LBA & Veropoulidou 2013 \\
\hline Nisi Eloundas & & $\mathrm{x}$ & & MBA & Brogan et al. 2012 \\
\hline Pacheia Ammos/Pefka & $\mathrm{x}$ & $\mathrm{x}$ & & MBA & Koh et al. 2016 \\
\hline Juktas & & $\mathrm{x}$ & & MBA & Reese 1987 \\
\hline Karoumes-Siteias & $\mathrm{x}$ & & & MBA & Brogan et al. 2012 \\
\hline Kastri & & $\mathrm{x}$ & & MBA & Stieglitz 1994: 52 \\
\hline Knossos & & $\mathrm{x}$ & & MBA & Ruscillo 2006 \\
\hline Kommos & $\mathrm{x}$ & $\mathrm{x}$ & $\mathrm{x}$ & MBA & Reese 1987; Ruscillo 2006 \\
\hline Kouphonisi & $\mathrm{x}$ & & & MBA & Brogan et al. 2012 \\
\hline Mallia & & $\mathrm{x}$ & & MBA & Reese 1987 \\
\hline Mochlos & & & $\mathrm{x}$ & MBA & Brogan et al. 2012 \\
\hline Monastiraki & & & $\mathrm{x}$ & MBA & Carannante 2014, with refs. \\
\hline Papadiokampos & & $\mathrm{x}$ & & MBA & Brogan et al. 2012 \\
\hline Chryssi & $\mathrm{x}$ & $\mathrm{x}$ & & MBA-LBA & Brogan et al. 2012; Koh et al. 2016 \\
\hline Lerna & & $\mathrm{x}$ & & MBA-LBA & Karali 1999: 56 \\
\hline Thessaloniki Toumba & $\mathrm{x}$ & $\mathrm{x}$ & $\mathrm{x}$ & MBA-EIA & Veropoulidou et al. 2008 \\
\hline Palaiokastro & $\mathrm{x}$ & & & MBA-Class. & Brogan et al. 2012; Reese 2000: 646 \\
\hline Makryialos & & & $\mathrm{x}$ & LBA & Reese 1987 \\
\hline Skala Sotiros & & $\mathrm{x}$ & & LBA & Karali 1999: 56 \\
\hline Akrotiri & & & $\mathrm{x}$ & LBA & Reese 1987 \\
\hline Chania & & & $\mathrm{x}$ & LBA & Alberti 2008: 79 with refs. \\
\hline Zakros & & & $\mathrm{x}$ & LBA & Alberti 2008: 79 with refs. \\
\hline Mitrou & & $\mathrm{x}$ & & LBA-EIA & Morgan 2007 \\
\hline Lefkandi & & $\mathrm{x}$ & & LBA-EIA & Morgan 2014 \\
\hline Agios Giorgios & $\mathrm{x}$ & $\mathrm{x}$ & & EIA & Reese 2000: 644 \\
\hline Asine & & $\mathrm{x}$ & & EIA & Reese 2000: 643 \\
\hline Methoni & & $\mathrm{x}$ & & EIA & Veropoulidou et al. 2008 \\
\hline Skiathos & & $\mathrm{x}$ & & EIA & Mazarakis-Ainan 2012 \\
\hline Athenian Agora & & $\mathrm{x}$ & & EIA? & Reese 2000: 644 \\
\hline Corinth & & $\mathrm{x}$ & & Arch. & Reese 2000: 644 \\
\hline Kallithea & $\mathrm{x}$ & & & Arch. & Morgan 2012 \\
\hline Salamina & $\mathrm{x}$ & $\mathrm{x}$ & & Class. & Morgan 2004 \\
\hline Delos & $\mathrm{x}$ & $\mathrm{x}$ & & Hell. & Zarmakoupi 2013 \\
\hline Lefkada & $\mathrm{x}$ & $\mathrm{x}$ & & Hell. & Morgan 2001 \\
\hline \multicolumn{6}{|l|}{ Israel } \\
\hline Tel Kabri & $\mathrm{x}$ & $\mathrm{x}$ & & EBA-EIA & Koren 2013: 53 figs. 5-6 \\
\hline Tell Abu Hawam & & $\mathrm{x}$ & & LBA & Baruch et al. 2005: 140-41, fig. 6 \\
\hline
\end{tabular}




\begin{tabular}{|c|c|c|c|c|c|}
\hline Site & Direct & $\begin{array}{l}\text { Debris } \\
\text { prim. }\end{array}$ & $\begin{array}{l}\text { Debris } \\
\text { redep }\end{array}$ & Chronology & References \\
\hline Akko & & $\mathrm{x}$ & & LBA-Hell. & Karmon and Spanier 1987: 151 fig. 6, 153 \\
\hline Tel Keisan & $\mathrm{x}$ & $\mathrm{x}$ & & EIA & Karmon and Spanier 1987: 149-51 \\
\hline Tel Mevorakh & & $\mathrm{x}$ & & EIA & Stern 1978: 25, 95 \\
\hline Tel Shiqmona & $\mathrm{x}$ & $\mathrm{x}$ & & EIA & $\begin{array}{l}\text { Karmon and Spanier 1987: 154-55, fig. } 9 \text {, } \\
\text { pl. A }\end{array}$ \\
\hline Apollonia/Arsuf & & $\mathrm{x}$ & & Class.-Hell. & Karmon 1999: 269-80 \\
\hline Tel Dor & $\mathrm{x}$ & $\mathrm{x}$ & & Class.-Hell. & Stern 1994: 198-99, figs. $132-34$ \\
\hline Tel Mor & $\mathrm{x}$ & $\mathrm{x}$ & & Class.-Hell. & Stern 1994: 195-98 \\
\hline \multicolumn{6}{|l|}{ Italy } \\
\hline Coppa Nevigata & & & $\mathrm{x}$ & EBA-MBA & Minniti 2005; Cazzella et al. 2005 \\
\hline Monte Grande & & & $\mathrm{x}$ & EBA-MBA & Bedini 1998 \\
\hline Taranto-Scoglio del Tonno & & $\mathrm{x}$ & & BA-Hell. & Guglielmino 2013 \\
\hline Roca & & & $\mathrm{x}$ & LBA & Guglielmino 2013 \\
\hline Scalo di Furno & & & $\mathrm{x}$ & LBA & Lo Porto 1990 \\
\hline Motya & $\mathrm{x}$ & & $\mathrm{x}$ & EIA & Reese 2005 \\
\hline Monte Circeo & & $\mathrm{x}$ & & Hell. & Blanc 1958 \\
\hline \multicolumn{6}{|l|}{ Lebanon } \\
\hline Tyre & & $\mathrm{x}$ & & BA-Roman & $\begin{array}{l}\text { Karmon and Spanier 1987: 149-51; Jensen } \\
\text { and Jensen 1965: 5, } 22\end{array}$ \\
\hline Sarepta & $\mathrm{x}$ & $\mathrm{x}$ & & LBA-EIA & $\begin{array}{l}\text { McGovern and Michel 1984: 67-68; Reese } \\
\text { 2010: 114, 118-19 }\end{array}$ \\
\hline Beirut & $\mathrm{x}$ & $\mathrm{x}$ & & EIA-Class. & Peyronel 2008: 62 \\
\hline Sidon & $\mathrm{x}$ & $\mathrm{x}$ & & EIA & Jensen and Jensen 1965: 5, 9, 22 \\
\hline \multicolumn{6}{|l|}{ Libya } \\
\hline Euesperides/Berenice & & $\mathrm{x}$ & & Class.-Hell. & Wilson et al. 2001 \\
\hline \multicolumn{6}{|l|}{ Morocco } \\
\hline Mogador & & $\mathrm{x}$ & & EIA & Alberti 2008: 78 with refs. \\
\hline \multicolumn{6}{|l|}{ Spain } \\
\hline Cerro del Castillo & & $\mathrm{x}$ & & EIA & Bueno 2014 \\
\hline Huelva & & $\mathrm{x}$ & & EIA & McGovern and Michel 1984 \\
\hline Morro de Mezquitilla & & $\mathrm{x}$ & & EIA & Schubart et al. 1969: 149 \\
\hline San Pablo & & $\mathrm{x}$ & & EIA & Fernández et al. 1997: 238 \\
\hline Teatro Cómico-Gadir & & $\mathrm{x}$ & & EIA & Gener et al. 2014 \\
\hline Toscanos & & $\mathrm{x}$ & & EIA & Uerpmann 1972 \\
\hline Cerro del Villar & $\mathrm{x}$ & $\mathrm{x}$ & & Arch. & Aubet 1997: 200 \\
\hline Sa Caleta & & $\mathrm{x}$ & & Arch. & Alfaro and Costa 2008; Costa 2011 \\
\hline Bahía del Salado & & $\mathrm{x}$ & & Hell. & Mederos and Escribano 2015: 362 \\
\hline $\begin{array}{l}\text { Calle Luis Milena, San } \\
\text { Fernando-Gadir }\end{array}$ & $\mathrm{x}$ & $\mathrm{x}$ & & Hell. & Bernal Cassola et al. 2011 \\
\hline
\end{tabular}




\begin{tabular}{|c|c|c|c|c|c|}
\hline Site & Direct & $\begin{array}{l}\text { Debris } \\
\text { prim. }\end{array}$ & $\begin{array}{l}\text { Debris } \\
\text { redep }\end{array}$ & Chronology & References \\
\hline \multicolumn{6}{|l|}{ Syria } \\
\hline $\begin{array}{l}\text { Ugarit (Ras Shamra) and } \\
\text { Minet el-Beidha }\end{array}$ & $\mathrm{x}$ & $\mathrm{x}$ & & LBA & Schaeffer 1951 \\
\hline Tell Rifaat & $\mathrm{x}$ & $\mathrm{x}$ & & Class.-Hell. & Seton-Williams 1967 \\
\hline \multicolumn{6}{|l|}{ Tunisia } \\
\hline Carthage & & $\mathrm{x}$ & & EIA & Zaouali 1994: 322 \\
\hline Kerkouane & & $\mathrm{x}$ & & EIA & Zaouali 1994: 322 \\
\hline Menninx, Djerba & & $\mathrm{x}$ & & Hell. & Wilson 2004: 160-61 \\
\hline \multicolumn{6}{|l|}{ Turkey } \\
\hline Troy & & & $\mathrm{x}$ & MBA & Çakirlar and Becks 2009 \\
\hline
\end{tabular}

\section{Preparation of Dyeing Substrate}

The stage at which dyeing took place depended on the nature of the fibre and the effect desired, taking account of the design of the textile and economic considerations of dye cost and product distribution. Written sources invariably mention sheep wool as the fibre of choice and note that it was usually dyed in the fleece, which would ensure maximum colour penetration (Macheboeuf 2004: 138; see also Ramig et al. 2017).

Wool had to be washed and degreased before being subjected to dyeing, to ensure chemical bonding between the fibre and the dye colourants (Cardon 2007: 11; see also Pliny the Elder 9.62). One of the vats at Middle Minoan Pefka on Crete had conspicuous traces of lanolin, indicating that it may have been used for washing raw wool (Koh et al. 2016). Dyed fibre would subsequently have to be spun and woven into fabric.

Yarn dyeing, meanwhile, would have required prior fibre preparation and spinning, with the threads carefully wound in loose skeins in order to prevent tangling and to ensure maximum dye penetration before introducing them into the vats. The advantage of dyeing fleece or yarn is that it would make it possible to use purple only on parts of the fabric, thereby saving on the precious material. In fact, most of the extant shellfish-purple-dyed textiles contain colourants in only one of the thread systems (see below).
Piece dyeing of the entire textile requires relatively large vessels to immerse it and move it around to ensure dye penetration, which would be more difficult because of the compact overlapping threads within the cloth. There appears to be little evidence for piece dying before the Roman period.

Dyeing

Given that dye components form quickly on exposure to air and light, it is likely that the first and simplest method was direct dyeing, achieved by rubbing the fibres/yarn/fabric with the mucus from the hypobranchial gland of the mollusc (see Figure 2, above; McGovern and Michel 1990: 154).

However, much better results are obtained by vat dyeing (Cardon 2007: 562), which involves reducing the indigoid colourants to their leuco form (the soluble form of the dye), so they can bind chemically to the textile fibre and become colourfast (McGovern and Michel 1990: 15456). For this, we have ethnographic evidence of traditional dyeing in Morocco. The process is achieved by adding wood ash lye or another source of alkali to the vat, to achieve $\mathrm{pH}$ 9. The vat is heated to approximately $50^{\circ} \mathrm{C}$ and kept under constant temperature, with light excluded, for seven to ten days. Wool is immersed in the vat for a few hours (see Figure 3), after which it is transferred into a covered container with 


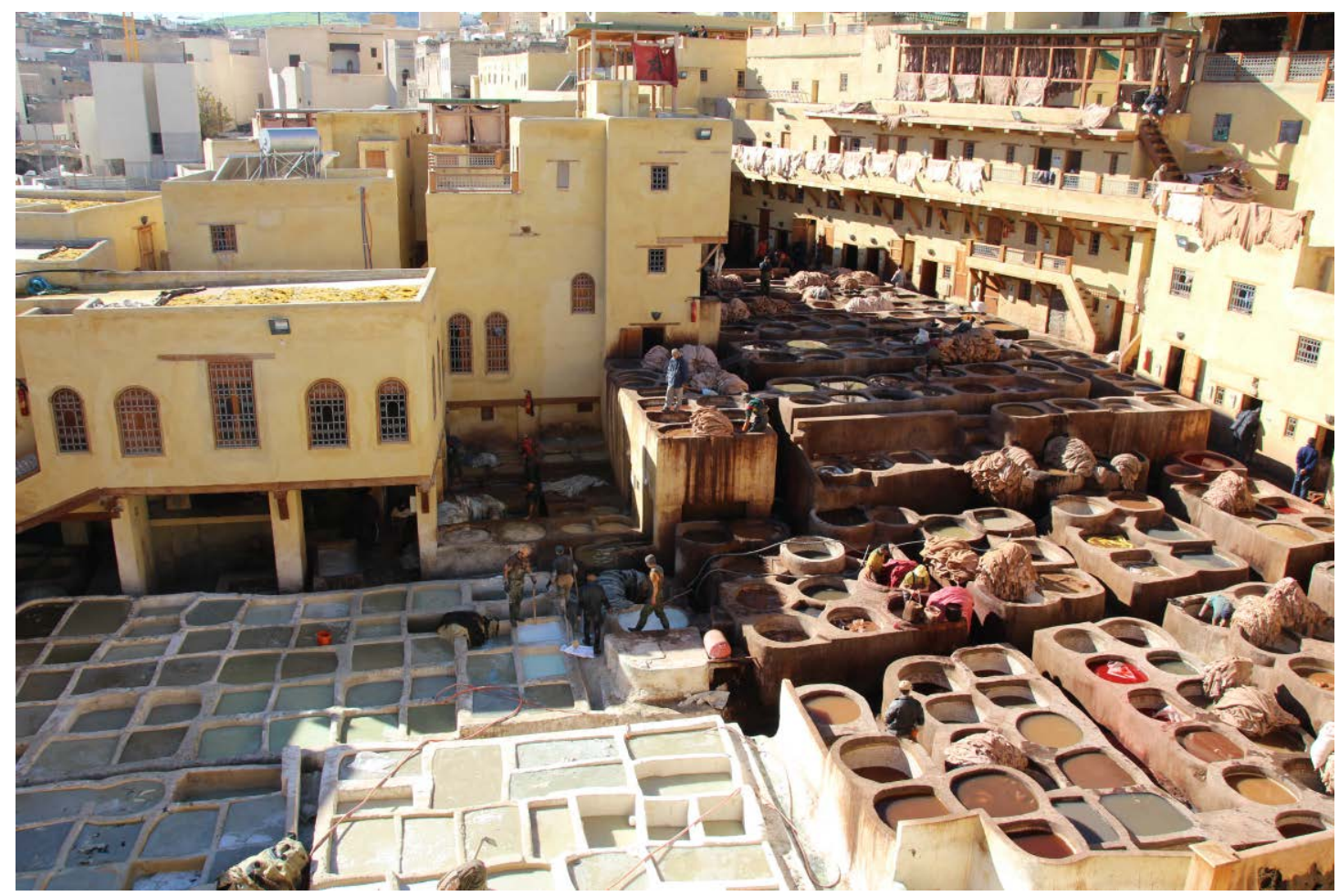

Figure 3. Dye workshop in Fez, Morocco (B. Marín-Aguilera).

water for an hour, where it achieves its final colour. The quantity of shellfish required in the ancient Mediterranean depended on the amount of fibre/yarn/cloth to be dyed and the desired colour hue, but experiments show that the early estimates, which reported a miniscule $0.1 \mathrm{mg}$ of dye per mollusc, were excessively small, as they were based on the amount of pure dye extract provided per mollusc (Burke 2010: 36). In fact, a significantly lower number of molluscs are needed (Koren 2005; Hopkins 2013).

Given that none of the dyeing tools or installations were specialised in the ancient Mediterranean, recognising a dye workshop is not straightforward, especially since dye extraction and dyeing need not have taken place in the same location. It is only the combination of structures, tools and residues that can provide sufficient evidence for interpreting a specific site as a purple-dye workshop.

The direct evidence for shellfish-purple dyeing is provided by containers that preserve purple traces, analytically proven to contain purple dye components. One of the earliest instances of such purple-stained vessels with crushed shells was found at the Middle Minoan site of Pefka on Crete (Apostolakou et al. 2016: 205). It has been claimed but not substantiated that two vats with purple residue were found in the so-called 'Textile Room' at Pyrgos Mavroraki on Cyprus, dated to the nineteenth century BC (Lentini 2009: 15371). Purple-stained pottery fragments or vessels have also been identified at Sarepta in Lebanon, dated to the thirteenth century BC (McGovern and Michel 1984: 67-68), at Tell Keisan in Israel and Tyre in Lebanon, both dated to the ninth century BC (Karmon and Spanier 1987: 14951) and at various later IA sites in Israel (Koren 1995). In most of these cases, dyeing appears to have been performed in relatively small containers, which in its turn suggests a small quantity of the resulting product.

Even so, because the temperature for vat dyeing does not need to exceed $50^{\circ} \mathrm{C}$, it is not incon- 
ceivable that wooden vats could have been used (Cardon 2007: 4). In Iberia, there is no evidence of purple-dye workshops until the third century BC, but it has been argued that, before Roman times, purple-dye installations were made of perishable materials (Alfaro and Costa 2008: 199).

The simplest heating facilities were probably hearths. Traces of burning mixed with crushed shells are usually considered as indicators of shellfish-purple production (Alberti 2008; Veropoulidou et al. 2008: 175; Apostolakou et al. 2016). Fuel sources are rarely considered in discussions of purple dyeing, although consistent access to fuel would have been fundamental in the process, given that heating would have been required at various stages (Hopkins 2013: 123). At Chryssi near Crete, the ash layer contained olive pits and almond shells, which were presumably used as fuel (Apostolakou et al. 2016: 203).

The location of dyeing workshops was likely affected by multiple factors, including the ecology of shellfish and access to water, salt and fuel, as well as to wool sources as seen, for example, at Taranto in Italy (Alfaro and Fernández 2017: 146). Furthermore, different types of production requiring the same or very similar equipment and resources were likely combined or located in close vicinity. At Pefka on Crete, there were multipurpose dyeworks (Apostolakou et al. 2016: 205 n. 34), whilst at Ugarit in Syria dye installations were connected with other sea activities in the harbour (Schaeffer 1951: 188-89); at Gadir in Spain, dyeworks and fisheries shared the same location (Bernal Cassola et al. 2011).

\section{Product}

Discussions of shellfish-purple dyeing often finish without considering the end product itself, even though extant textile remains containing brominated compounds constitute the most important evidence and irrefutable proof of shellfish-purple dyeing (see Table 2). They also provide an important geographical, chronological and technological dimension to our understanding of shellfish-purple consumption (Figure 4).
Although not numerous, extant shellfishpurple-dyed textiles provide information about the types and qualities of textiles dyed with shellfish-purple- their raw material and technical characteristics-and allow us to draw some conclusions about the stage in the textile production process during which dyeing took place (Figures 5 and 6). Most textiles are of very high quality.

Where identified, the material is sheep wool. Most of the textiles are weft-faced tabbies which have at least twice as many wefts as warp threads per unit of length. In all but one of these weftfaced tabbies, shellfish-purple colourants are present only in one system, the weft. In contrast, the only tablet-woven textile, a technique typical for Italy and central Europe but so far unattested in Greece and the Near East (Gleba 2017), has purple warp. Thus in both techniques it is the more visible thread system that was coloured: the precious dye was not wasted on the less prominent structural element. This provides irrefutable evidence that most of the textiles were dyed at either wool or skein stage, not as finished cloth, as frequently suggested; this also confirms information provided by written sources and archaeometric analyses of existing dye vats (e.g. Koh et al. 2016).

\section{The Emergence of Shellfish-purple}

Most of the early archaeological purple-dyed textiles come from high-prestige contexts (Qatna in Syria, Stamna in Greece). Indeed, the social significance and potentially high value appear to have been common attributes of purple-dyed textiles in the Near East and the Aegean at least since the Bronze Age, when they seem to be regularly connected to royalty and gods. Purple-dyed textiles were widely used to pay tribute to both royal courts and temples, according to administrative records in the Near East (Soriga 2017: 90-91). Ugarit, for instance, sent an annual tribute to the Hittites that included blue-purple wool and 500 shekels 
Table 2. Sites with purple-dyed textile remains (M. Gleba).

\begin{tabular}{|c|c|c|c|c|c|c|}
\hline Site & Context & Chronology & Textile type(s) & Material & Purple element & Reference \\
\hline \multicolumn{7}{|l|}{ Greece } \\
\hline Stamna & $\begin{array}{l}\text { Burials in bronze } \\
\text { cauldrons }\end{array}$ & $\begin{array}{r}\text { ca. } 1200- \\
1000 \text { вС }\end{array}$ & Weft-faced tabby & Wool? & Weft bands & Kolonas et al. 2017 \\
\hline Corfu & Tomb 24 & $\begin{array}{l}\text { Late } 7 \text { th- } \\
\text { early 6th } \\
\text { cent. BC }\end{array}$ & Weft-faced tabby & Wool & Unknown & Metallinou et al. 2009 \\
\hline $\begin{array}{l}\text { Kalyvia, } \\
\text { Attica }\end{array}$ & Burial & $\begin{array}{l}\text { 5th cent. } \\
\text { BC }\end{array}$ & $\begin{array}{l}\text { Weft-faced tabby } \\
\text { with purple } \\
\text { stripe }\end{array}$ & Wool & Weft of stripe & $\begin{array}{l}\text { Spantidaki 2016: } 110 \\
\text { cat. nos. 6, } 121\end{array}$ \\
\hline $\begin{array}{l}\text { Kerameikos, } \\
\text { Athens }\end{array}$ & Burial & $\begin{array}{l}\text { 5th cent. } \\
\text { BC }\end{array}$ & Weft-faced tabby & Wool & weft & $\begin{array}{l}\text { Margariti et al. 2013; } \\
\text { Spantidaki } 2016 \text { : } \\
112 \text { cat. no. } 12 \text {, } \\
128-29\end{array}$ \\
\hline $\begin{array}{l}\text { Maroussi, } \\
\text { Attica }\end{array}$ & Burial & $\begin{array}{l}\text { 5th cent. } \\
\text { BC }\end{array}$ & Weft-faced tabby & Wool & Warp and weft & $\begin{array}{l}\text { Spantidaki 2016: } 113 \\
\text { cat. nos. } 18,135\end{array}$ \\
\hline $\begin{array}{l}\text { Aigai } \\
\text { (Vergina) }\end{array}$ & $\begin{array}{l}\text { Burials of Philip } \\
\text { II and young } \\
\text { woman }\end{array}$ & $\begin{array}{l}\text { 4th cent. } \\
\text { BC }\end{array}$ & Tapestry & Wool? & Unknown & $\begin{array}{l}\text { Andronikos 1984: } \\
\text { 164, fig. 140; } \\
\text { Cardon 2007: } 573\end{array}$ \\
\hline \multicolumn{7}{|l|}{ Italy } \\
\hline Cumae & $\begin{array}{l}\text { Burial, Fondo } \\
\text { Artiaco } 104, \\
\text { attached to } \\
\text { bronze cauldron }\end{array}$ & са. 730 вс & Weft-faced tabby & Wool & Weft & $\begin{array}{l}\text { Gleba and Vanden } \\
\text { Berghe } 2018\end{array}$ \\
\hline $\begin{array}{l}\text { Tarquinia, } \\
\text { Doganac- } \\
\text { cia }\end{array}$ & $\begin{array}{l}\text { Burial, Tomba } \\
\text { dell'aryballos } \\
\text { sospeso, inside } \\
\text { bronze pyxis }\end{array}$ & са. 600 вс & Tablet weave & Wool & Warp & Gleba et al. 2017b \\
\hline $\begin{array}{l}\text { Strozzacap- } \\
\text { poni, } \\
\text { Perugia }\end{array}$ & Burials & $\begin{array}{l}\text { 2nd cent. } \\
\text { BC }\end{array}$ & Weft-faced tabbies & Unknown & $\begin{array}{l}\text { Weft, discon- } \\
\text { tinuous }\end{array}$ & Gleba et al. $2017 \mathrm{a}$ \\
\hline \multicolumn{7}{|l|}{ Spain } \\
\hline Gadir & $\begin{array}{l}\text { Burial, monumen- } \\
\text { tal tomb, mixed } \\
\text { with plaster and } \\
\text { gold threads }\end{array}$ & $\begin{array}{l}\text { 6th cent. } \\
\text { BC }\end{array}$ & Unknown & Unknown & Unknown & $\begin{array}{l}\text { Domínguez-Bella et } \\
\text { al. } 2011\end{array}$ \\
\hline \multicolumn{7}{|l|}{ Syria } \\
\hline $\begin{array}{r}\text { Chagar } \\
\text { Bazar }\end{array}$ & Burials 110, 118 & $\begin{array}{l}\text { 18th-16th } \\
\text { cent. BC }\end{array}$ & $\begin{array}{l}\text { Looping or knot- } \\
\text { less netting }\end{array}$ & Wool & $\begin{array}{c}\text { Decorative } \\
\text { element? }\end{array}$ & Breniquet et al. 2018 \\
\hline $\begin{array}{l}\text { Qatna (Tell } \\
\text { Mishrife) }\end{array}$ & $\begin{array}{l}\text { Royal Burial, floor } \\
\text { of the burial }\end{array}$ & $\begin{array}{l}\text { Bronze } \\
\text { Age, } \\
\text { terminus } \\
\text { ante quem } \\
1340 \mathrm{BC}\end{array}$ & $\begin{array}{l}\text { Weft-faced tabby } \\
\text { with tapestry } \\
\text { meander pattern }\end{array}$ & Wool & $\begin{array}{l}\text { Weft of mean- } \\
\text { der pattern }\end{array}$ & $\begin{array}{l}\text { James et al. 2009; } \\
\text { Reifarth and } \\
\text { Drewello } 2011\end{array}$ \\
\hline
\end{tabular}




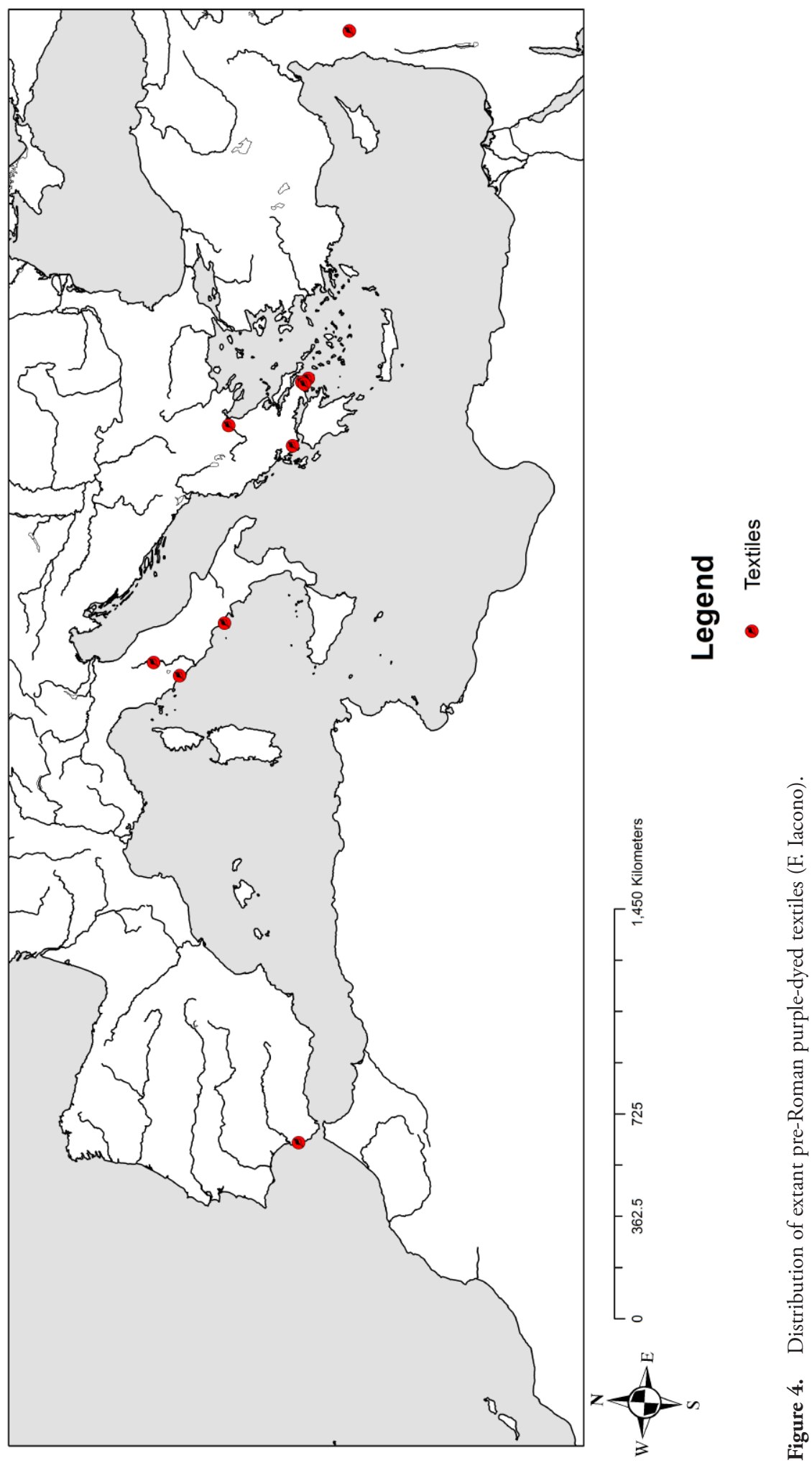




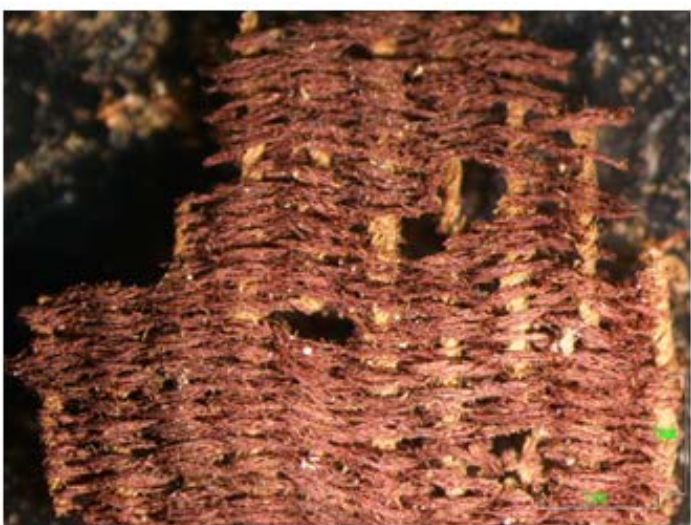

a.

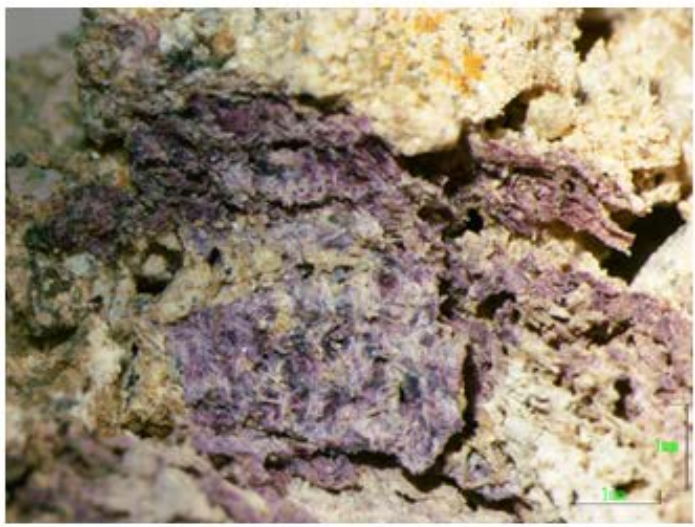

c.

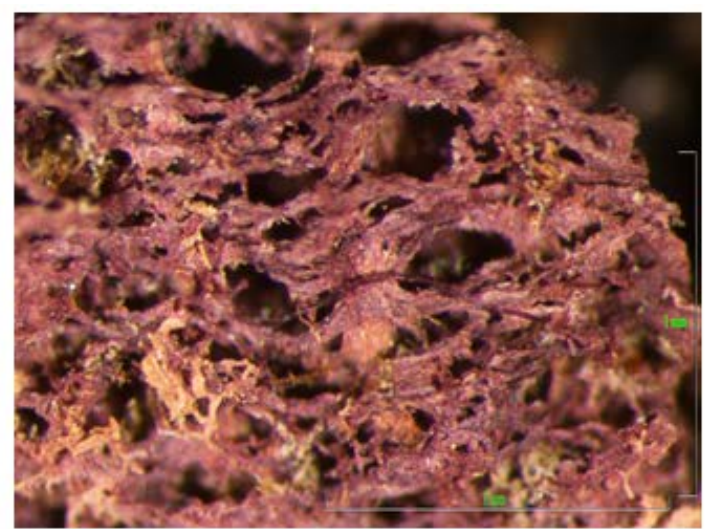

b.

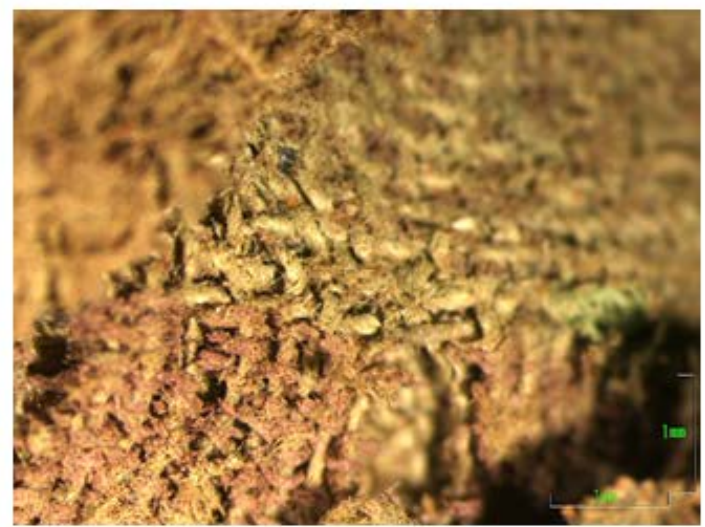

d.

Figure 5. Shellfish-purple-dyed textiles: (a-b) Kerameikos, Athens, Greece, fifth century вс; (c) Maroussi, Greece, fifth century BC; (d) Kalyvia, Greece, fifth century вс (Hellenic Centre for Research and Conservation for Archaeological Textiles-ARTEX).

of red-purple wool (Singer 2008: 29). A later inscription of Shalmaneser III states that Tyre and Sidon sent blue and red woolen textiles to the Assyrian king (Soriga 2017: 80).

In the Aegean world, Burke (2010) suggests, purple-dyed textiles contributed to the development of the Minoan economy and long-distance trade. Purple-dyed textiles are mentioned in the Linear B archives of Knossos, suggesting the palace's interest in these goods. Whether this translated into an active control of their production (and/or consumption) is unclear, although the association of the term po-pu-re-ja (Linear $\mathrm{B}$ equivalent of purple) with wa-na-ka-te-ro ('palace, house of the king') in the tablet KN X
976 clearly suggests that at least some subset of purple textile production was considered to be 'royal' (Burke 2010; Del Freo et al. 2010).

With the Late Bronze Age collapse of the palatial systems in the Near East and the Aegean, however, the social and political value of purple-dyed textiles arguably changed. Indeed, as Bronze Age notions of royalty and authority were changing, so too were the symbols related to them. Western influences in eastern societies of post-collapse Bronze Age also entailed the appropriation of new ideas about clothing, embodied in the wide distribution of objects such as fibulae (Sherratt 2000; Iacono 2013). These ideas, arguably, blended with pre-existing 


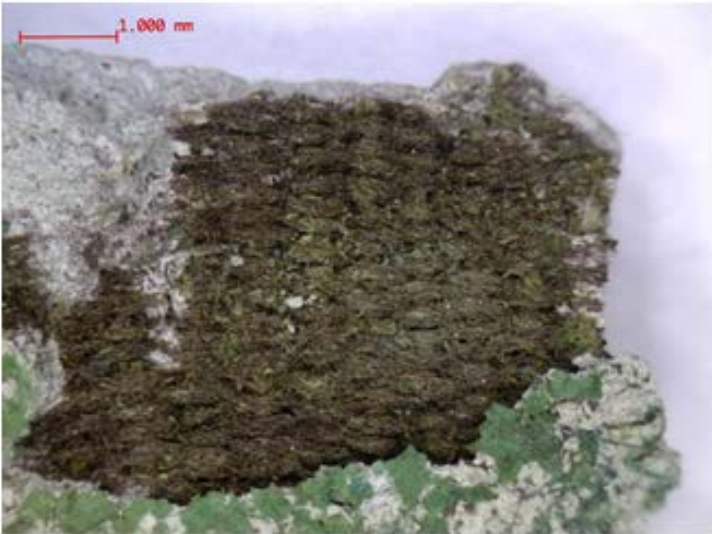

a.

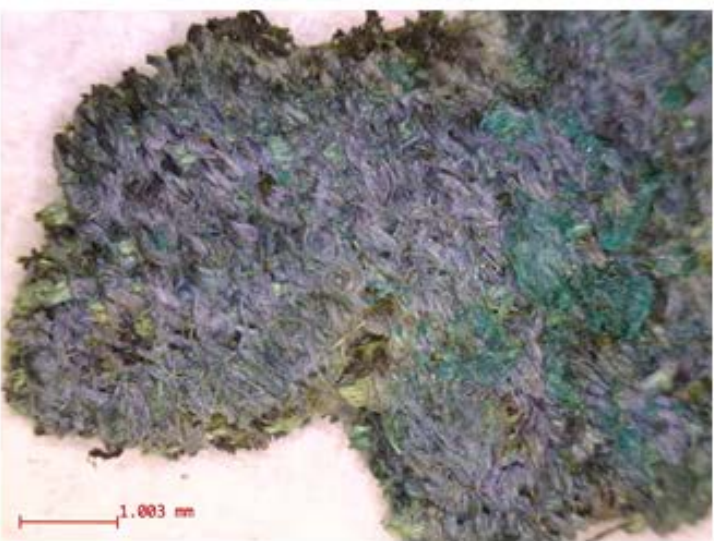

c.

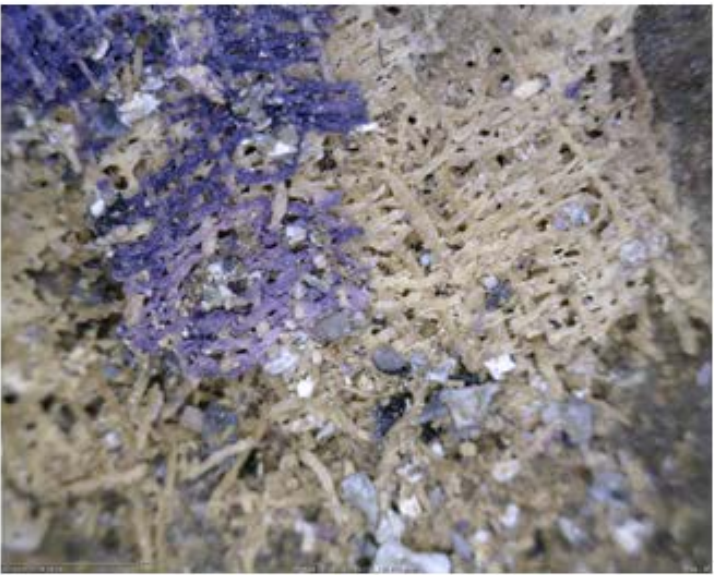

e.

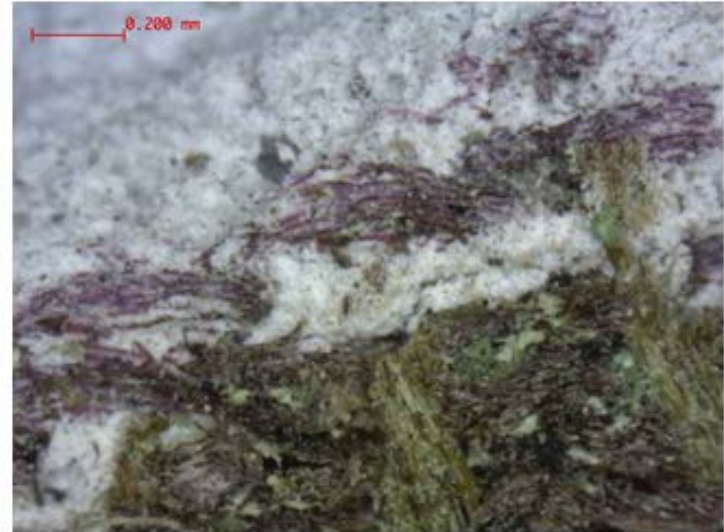

b.

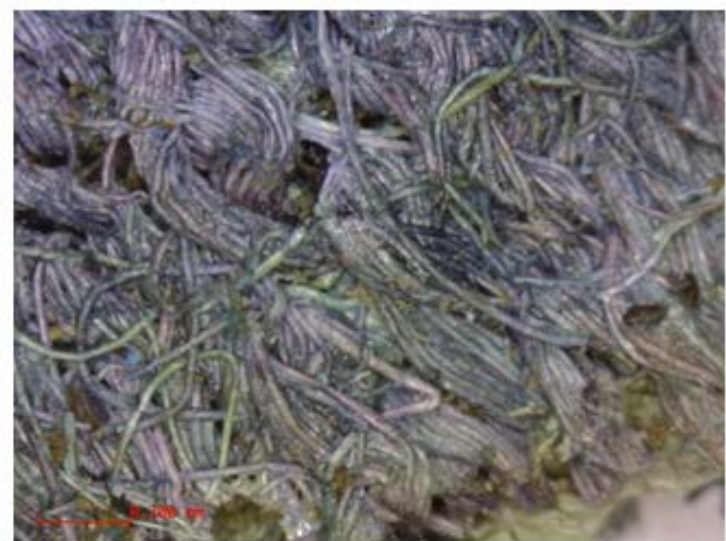

d.

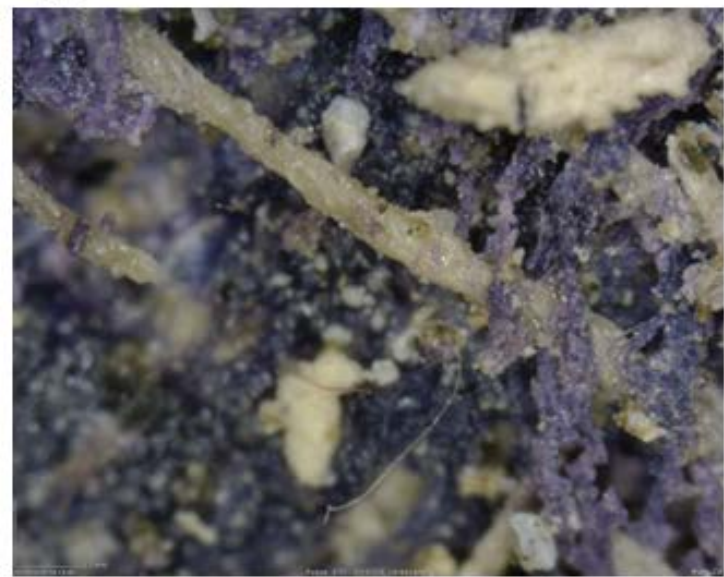

f.

Figure 6. Shellfish-purple-dyed textiles: (a-b) Cumae, Italy, eighth century BC; (c-d) Tarquinia, Italy, sixth century BC; (e-f) Strozzacapponi, Italy, second century вс (M. Gleba). 
palatial textile traditions, creating a new taste. Such transformations almost certainly would have repercussions in the will to continue to use the highly valued purple-dyed textiles, which, as we have seen, were a long-lasting symbol of 'palatial elites'. The fact that purple-dye production possibly continued into the first millennium BC at Lefkandi in Greece, where 'westernising' features are attested, may be indicative of some continuity, but with the adaptation of purple dyeing (and related textiles) to new tastes (Reese 2006; Morgan 2014). Indirect evidence of wool dyeing is also provided by Homer's description of Helen of Troy, who is depicted as wielding a golden distaff decorated with violet wool (Odyssey 4.133-36).

In the central Mediterranean, early evidence for purple production is concentrated in Apulia (Italy), with the site of Coppa Nevigata presenting evidence for shellfish processing from the nineteenth and eighteenth centuries BC onwards (Cazzella et al. 2005; Minniti 2005). It has been suggested (Cazzella et al. 2005) that purple technology at Coppa Nevigata was connected to external demand from the Aegean world, but it is more likely that the principal sphere of circulation and consumption of purple-dyed textiles was local. Coppa Nevigata had declined by the thirteenth to twelfth century $\mathrm{BC}$, and purple production re-emerged again in the area only after the foundation of the Greek settlement of Tarentum in the late eighth century $\mathrm{BC}$, suggesting that rather than presenting technological continuity, the area had favourable ecological and economic conditions for purple exploitation. Over the course of the first millennium $\mathrm{BC}$, the evidence for shellfish-purple production increases across the central Mediterranean (see Table 1).

The number and distribution of sites with evidence of purple production increased and expanded westward during the Bronze Age and IA (Figures 7 and 8), with the western Mediterranean and the north and northwest coast of Africa developing purple-dye production only during the latter period, in close connection with the arrival of the Phoenicians (see Table 1). Crushed purple-shell debris has been found on Phoenician and Punic sites in these regions, and its quantity increased in number from the sixth century BC onwards, as at Carthago Nova in Murcia, Spain (Carrasco 2004) and on the Balearic island of Ibiza (Costa 2011). However, there are fewer purple-producing sites in the central and western Mediterranean than in the east, and while in the eastern regions there is both direct evidence (stained vessels, vats, hearths, workshops) and indirect evidence (debris) of purple production, the archaeological record in the centre and west points only to indirect evidence, with the exception of Motya (off the west coast of Sicily), Cerro del Villar and Gadir (respectively, in southeast and southwest Iberia)-elsewhere, there is no evidence of burning mixed with crushed shells.

This may reflect the point made above that purple dye installations were made of perishable materials and thus did not survive. The absence of workshops in these areas could also be related to the fact that many ancient sites cannot be (fully) excavated because they are covered by modern habitations. It could also indicate small-scale production (Veropoulidou et al. 2008). Another possibility might be that dyers in these regions used direct rather than vat dyeing. This would mean that the number of dyed textiles and thus the scale of production were potentially more limited than in the eastern Mediterranean during the same period.

\section{The Social Value of Purple-dyed Textiles}

\section{Globalisation of Shellfish-purple}

Over the course of the first millennium BC, purple technology appears to spread more widely across the Mediterranean. The seventh century BC, generally coinciding with the so-called Orientalising period, has been key in linking the eastern Mediterranean with the central and western regions (Burkert 1992; Celestino and Jiménez 2005; Riva 2010), in particular 


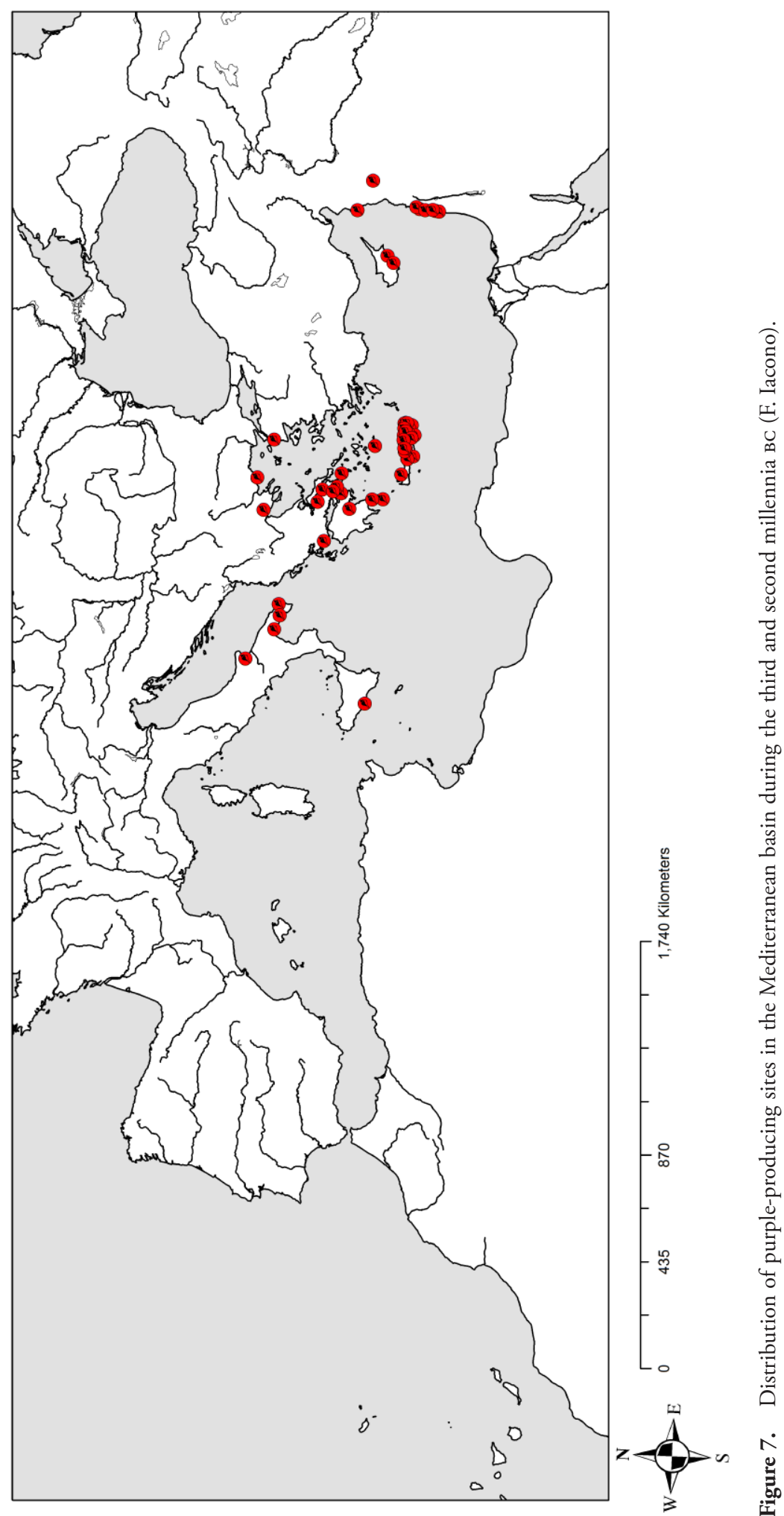




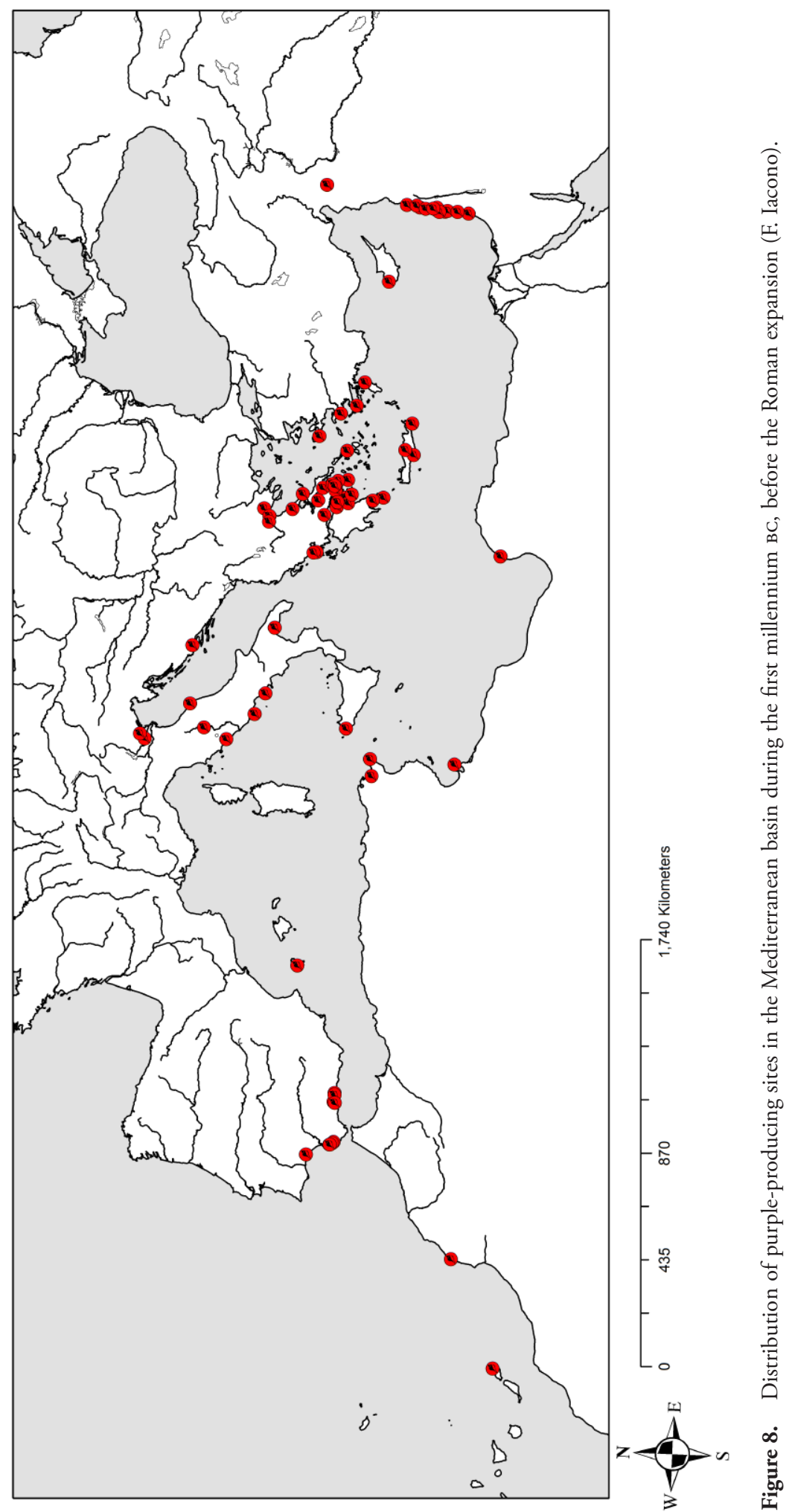


through the establishment of Phoenician and Greek settlements (Aubet 2001; Hurst and Owen 2005; Tsetskhladze 2006). The renewed connectedness of this period, framed as a globalisation process (Hodos 2017: 4), was characterised by the development of shared practices across the Mediterranean and by an increasing awareness of cultural differences.

Like other elements of the Mediterranean package such as oil and probably wine (Riva 2010), after an initial period of parallel multiregional 'incubation', shellfish-based dye technology gradually spread throughout the Middle Sea. Phoenicians and Greeks were crucial in promoting the spread of common ideologies and consumption practices among distant elites in the Near East, Greece, Italy, northwest Africa and Iberia (Celestino and Jiménez 2005; Feldman 2014). In these shared practices, the consumption of purple-dyed textiles likely played a key role in elite discourses and self-legitimation.

The intense colour of these textiles was also of importance for the development of a community of shared style among Mediterranean elites (sensu Feldman 2014), insofar as it was associated in the east with royalty and priesthood (Jensen and Jensen 1965). Especially important was the fact that shellfish-dyed textiles were colourfast, i.e. their colour could remain bright for centuries after manufacture. These associations, together with the time-consuming production process, made these textiles particularly desired across the Mediterranean and into a status symbol indicating the elevation of certain social groups over others.

However, in the globalised world of the late first millennium BC Mediterranean, production and consumption did not necessarily coincide. Thus, Iberia initially appropriated the chromatic grammar of the purple dye only from a consumption perspective. Shells of all three mollusc species used for the production of purple dye have been identified on various Iberian sites, but appear to have been used only for alimentary purposes (Pascual 2014). There is only one indigenous site, San Pablo, located $6 \mathrm{~km}$ from the Phoenician colony of Cerro del Villar, that has provided evidence of shell debris (Fernández et al. 1997). Otherwise, no evidence for the production of shellfish-purple dye has been recovered from indigenous sites in pre-Roman Iberia. This indicates that indigenous communities in Iberia, the Balearics, the Canary Islands and North Africa were likely consuming but not producing purple-dyed textiles before Roman times. It also points to an exclusive Phoenician and Punic control of production and trade of shellfish-purple-dyed textiles within local communities in these territories.

\section{Democratisation of Shellfish-purple}

By the third century BC, there was an expansion of purple dye workshops and a significant increase in the number and size of crushed shell heaps across the Mediterranean basin, the Atlantic coast of North Africa and the Canary Islands. The production and consumption of shellfish-dyed textiles became democratised in the sense of reaching across the social spectrum, despite simultaneously and paradoxically reinforcing social differentiation. For the first time in history, purple-dyed textiles became easily available not only to royalty, aristocracy and the high priesthood, but also to other social strata. Undoubtedly, fully purple-dyed textiles would have been extremely expensive, but small quantities of fine purple yarn could go a long way to satisfy what Pliny the Elder (9.60) later called the 'purple mania'. Indeed, the latest in our list of extant shellfish-purple-dyed textiles from Strozzacapponi, in central Italy, derives from a quarry workers' cemetery (Gleba et al. 2017a).

The very fact that Pliny (9.64) distinguished between low- and high-quality purple textiles is indicative of the existence of a spectrum of differentiated products. Their value depended on the colour and its saturation, which in turn depended on the fashion of the moment (e.g. Marzano 2013: 148; Meiers 2017). Because of the high value of shellfish-purple, it did not take 
long before it began to be imitated using other dye sources, for example the combination of red dye from the roots of the Rubiaceae family and blue dye derived from the woad plant, Isatis tinctoria (Wouters et al. 2008), or by using lichens such as Roccella tinctoria (Mederos and Escribano 2015: 349-54). Given the popularity of the colour purple and the variety of shades available, it was not always easy to distinguish between real shellfish-purple and counterfeit products.

Thus at Strozzacapponi we have a paradoxical situation, where one of the richest tombs contained a textile dyed with non-shellfish purple, while the finest shellfish-purple-dyed cloth was found in a humble coarse-ware ossuary (Gleba et al. 2017a). To what extent the consumers could (or cared to) distinguish between 'true' and 'fake' purple is a different matter.

\section{Concluding Remarks}

Discussions of purple dyeing in the ancient Mediterranean have permeated academic books, articles and debates for over a century, to a degree that perhaps exaggerates the scale of mollusc dye production. Much of Bronze Age and IA production seems to have been small in scale, with outputs limited in size and quantity. This is suggested by the small size of many of the vessels and vats used for production, as well as the small scale of the facilities themselves. Apart from a very few exceptions, there is no increase in scale until Roman times, when workshops grow immensely in size, resulting in a greater production output and accessibility of the product.

The local and regional context is crucial to the understanding of production, consumption and significance of purple-dyed textiles. Used mainly by the palace and temple elites in the Near East and Aegean during the Bronze Age, purple-dyed textiles became more widespread during the IA. In Italy, their production appears to have been limited to Apulia during the Bronze Age and expanded more widely only during the first millennium $\mathrm{BC}$, whereas in the western Mediter- ranean and along the Atlantic coast of Morocco, it only began in the IA, associated with the establishment of permanent Phoenician/Punic settlements. The increase and spread of workshops and production areas across the Mediterranean was decisive for the circulation and adoption of purple-dyed textiles among Mediterranean elites, and was closely connected with the appropriation of a series of practices and objects originally from the Near East. If in the seventh and sixth centuries BC purple-dyed textiles served as a social and political legitimation tool for Mediterranean elites, by the second century $\mathrm{BC}$ wider segments of the population had appropriated them to access new social ladders, e.g. those connected to the new social organisation of large Hellenistic kingdoms and related emerging urban markets (whose analysis goes beyond the scope of this paper). The purple-dyed cloth found in the humble clay ossuary at Strozzacapponi mentioned above blurred social boundaries, as the deceased and their family apparently tried to display greater social and economic status than was actually the case. An elite tomb in the same cemetery, by contrast, opens an interesting discussion on the dyers' advanced skill in imitating purple-dyed textiles using vegetal dyes (Gleba et al. 2017a). Was this a case of deliberate fraud? Did it even matter that the dye was not derived from the precious shellfish as long as everyone else thought it was?

Over time, the consumption of purple-dyed textiles mutated, starting out as the privilege of kings, trickling down to increasingly wider social groups and finally becoming democratised by the end of the first millennium BC, only to become a monopoly of Roman and Byzantine rulers before the technology was lost.

The comparison of different Mediterranean regions, the study of the full chaine opératoire of purple-dyed textiles, and the examination of the local context has enabled us to gain a better, albeit more complex, understanding of the production, consumption and significance of these textiles in pre-Roman times. Future 
chemical analysis of purple-dyed textiles will no doubt expand the corpus of evidence regarding their technological and consumption patterns. More detailed work on shell fragmentation, archaebotanical remains and geomorphology should allow a much deeper interpretation of production sites. It is also our hope that classical scholarship dealing with purple dye will explore more peripheral yet fundamental aspects of purple production and consumption, as has been done recently with regard to fishing rights in ancient Greece (Alfaro and Fernández 2017). As the field of purple studies accumulates an ever-greater mass of evidence, it is time we start using it to explore broader questions.

\section{Notes}

1. BMA collected data on purple-dye production in Cyprus, the Near East, North Africa, Portugal and Spain; FI collected data in Greece, Italy and Turkey and produced the maps; MG collected data on the chaine opératoire and textile analyses. All authors contributed to the writing and organisation of the paper.

2. It is impossible to provide a complete list of references on shellfish-purple in the space allotted; we therefore limit ourselves to the most recent or seminal publications, which can be consulted for additional references. For an extensive and upto-date bibliography, see http://www.chriscooksey.demon.co.uk/tyrian/cjcbiblio.html.

\section{Acknowledgments}

The research leading to these results received funding from the European Research Council under the European Union's Seventh Framework Programme (FP/2007-2013-312603), and was carried out within the scope of the project Production and Consumption: Textile Economy and Urbanisation in Mediterranean Europe 1000-500 $B C E(P R O C O N)$. Access to textiles in Italy was kindly provided by the Soprintendenze for the Archaeological Heritage of Lazio-Etruria Merid- ionale and Umbria. We thank Stella Spantidaki for the images of Greek textiles, and we are grateful to Corinna Riva and JMA's reviewers for their insightful comments on an earlier version of this paper. All remaining opinions and errors are our own.

\section{About the Authors}

Beatriz Marín-Aguilera is currently a Renfrew Fellow at the McDonald Institute for Archaeological Research at the University of Cambridge, UK. She was awarded her PhD in Archaeology by the Universidad Complutense de Madrid, Spain. While doing her $\mathrm{PhD}$, she was based for a year at the University of Glasgow, for three months at the Spanish School for Archaeology in Rome, and three months at Brown University. Her research focuses on the archaeology of cultural contact and colonialism, particularly on the role of architecture, food habits and clothing in shaping borderland identities and power relationships in colonial situations.

Francesco Iacono is currently a Marie Skłodowska Curie Research Fellow at the McDonald Institute for Archaeological Research, University of Cambridge, UK. He was previously a Postdoctoral researcher at the Institute of Aegean Prehistory. He completed his postgraduate education (both $\mathrm{MA}$ and $\mathrm{PhD}$ ) at University College London. While doing his $\mathrm{PhD}$, he was based for a year at the British School at Athens as MacmillanRodewald Fellow. His research interests range in scope from cultural heritage to Mediterranean archaeology, with a specific focus on Bronze Age connections between the Aegean and the central Mediterranean and the use of formal network methods to analyse them.

Margarita Gleba is currently ERC Principal Research Associate at the McDonald Institute for Archaeological Research, University of Cambridge, UK. She was previously a research project manager at the Centre for Textile Research, 
University of Copenhagen, Denmark, and Marie Curie Fellow at University College London. Her research interests include the archaeology of the pre- and protohistoric Mediterranean and Near East. She specialises in textile archaeology, including scientific analytical methods of fibre and textile investigation.

\section{Classical Authors and Texts}

Aristotle, History of Animals.

Homer, Odyssey.

Pliny the Elder, Natural History.

\section{References}

Alberti, M.E.

2006 La prima porpora: primato etnico o comune patrimonio mediterraneo? In A. Cardarelli, M. Pacciarelli and A. Vanzetti (eds.), Studi di Protostoria in onore di Renato Peroni, 733-36. Florence: All'Insegna del Giglio.

2008 Murex shells as raw material: the purple-dye industry and its by-products. Interpreting the archaeological record. KASKAL 5: 73-90.

Alfaro, C., and B. Costa

2008 Methodological aspects of purple dye production in Ibiza: the new site of Cala Olivera. In C. Alfaro and L. Karali (eds.), Purpureae Vestes II. Vestidos, Textiles y Tintes. Estudios Sobre la Producción de Bienes de Consumo en la Antigüedad, 195-208. València: Universitat de València.

Alfaro, C., and F.J. Fernández

2017 'Purple Wars': fishing rights and political conflicts concerning the production of marine dyes in Hellenistic Greece. In H. Landenius Enegren and F. Meo (eds.), Treasures from the Sea: Sea Silk and Shellfish Purple Dye in Antiquity, 14553. Oxford: Oxbow Books.

Alfaro, C., and D. Mylona

2014 Fishing for purple shellfish (Muricidae) in ancient Greece: acquisition technology and first steps in purple dye production. In C. Alfaro, J.P. Wild and B. Costa (eds.), Purpureae Vestes IV. Production and Trade of Textiles and Dyes in the Roman Empire and Neighbouring Regions, 149-65. València: Universitat de València.
Alfaro, C., J.P. Wild and B. Costa (eds.)

2004 Purpureae Vestes. Textiles y Tintes del Mediterráneo en Época Romana. València: Universitat de València.

Andersson Strand, E.

2015 The basics of textile tools and textile technology - from fibre to fabric. In E.B. Andersson Strand and M.-L. Nosch (eds.), Tools, Textiles and Contexts: Investigating Textile Production in the Aegean and Eastern Mediterranean Bronze Age, 39-60. Oxford: Oxbow Books.

Andronikos, M.

1984 Vergina: The Royal Graves. Athens: Ekdotike. Apostolakou, S., P. Betancourt, T. Brogan and D. Mylona

2016 Chryssi and Pefka: the production and use of purple dye on Crete in the Middle and Late Bronze Age. In J. Ortiz, C. Alfaro, L. Turell and M.J. Martínez (eds.), Purpureae Vestes V. Textiles, Basketry and Dyes in the Ancient Mediterranean World, 199-208. València: Universitat de València.

Attema, P., J. Seubers and S. Willensen (eds.)

2016 Early States, Territories and Settlements in Protohistoric Central Italy. Groningen: University of Groningen. https://doi.org/10.2307/j. ctt2204s9x

Aubet, M.E.

1997 Un lugar de mercado en el Cerro del Villar. In M.E. Aubet (ed.), Los fenicios en Málaga, 197213. Málaga: Servicio de Publicaciones de la Universidad de Málaga.

2001 The Phoenicians and the West: Politics, Colonies, and Trade. Cambridge: Cambridge University Press.

Baruch, I., M. Artzy, J. Heller, J. Balensi and M.D. Herrer 2005 The mollusc fauna from the Late Bronze and Iron Age strata of Tell Abu Hawam. In D.E. Bar-Yosef Mayer (ed.), Archaeomalacology: Molluscs in Former Environments of Human Behaviour, 137-47. Oxford: Oxbow Books.

Bedini, E.

1998 I reperti faunistici del deposito votivo del Bronzo Antico di Monte Grande. In G. Castellana (ed.), Il Santuario Castellucciano di Monte Grande e l'Approvvigionamento dello Zolfo nel Mediterraneo nell'Età del Bronzo, 432-58. Agrigento, Italy: Regione Sicilia, Agrigento. 
Bernal Casasola, D., A. Sáez Romero and M. Bustamante Álvarez

2011 Entre la pesca y la púrpura en el Gadir tardopúnico. Actuación arqueológica en el conchero de la C/ Luis Milena (San Fernando, Cádiz). In C. Alfaro, J.-P. Brun, P. Borgard and R. Pierobon Benoit (eds.), Purpureae Vestes III. Textiles y Tintes en la Ciudad Antigua, 157-80. València: Universitat de València.

Blanc, A.C.

1958 Testimonianze di manifattura di porpora al Monte Circeo ed a Leptis Magna. Quaternaria 5: 320-26.

Bonet-Rosado, H., and C. Mata-Parreño

2015 Who lives there? Settlements, houses and households in Iberia. In A.B. Knapp and P. van Dommelen (eds.), The Cambridge Prehistory of the Bronze and Iron Age Mediterranean, 471-87. New York: Cambridge University Press.

Breniquet, C., S. Desrosiers, W. Nowik and A. Rast-Eicher 2018 Les textiles découverts dans les tombes de l'âge du Bronze moyen à Chagar Bazar, Syrie. In Ö. Tunca and A. Baghdo (eds.), Chagar Bazar (Syrie) VIII. Les tombes ordinaires de l'âge $d u$ Bronze ancien et moyen des chantiers D-F-H-I (1999-2011). Études diverses, 11-32. Leuven: Peeters.

Brogan, T.M., P.P. Betancourt and V. Apostolakou

2012 The purple dye industry on eastern Crete. In R. Lafineur and M.-L. Nosch (eds.), KOSMOS: Jewellery, Adornment and Textiles in the Aegean Bronze Age. Aegaeum 33: 187-93. Liège: Peeters.

Bueno, P.

2014 Un asentamiento del Bronce Final-Hierro I en el Cerro del Castillo, Chiclana, Cádiz. Nuevos datos para la interpretación de Gadeira. In M. Botto (ed.), Los fenicios en la Bahía de Cádiz. Nuevas investigaciones, 225-51. Rome: Fabrizio Serra.

Burke, B.

2010 From Minos to Midas: Ancient Cloth Production in the Aegean and in Anatolia. Oxford: Oxbow Books.

Burkert, W.

1992 The Orientalizing Revolution: Near Eastern Influence on Greek Culture in the Early Archaic Age. Cambridge, Massachusetts: Harvard University Press.
Çakirlar, C., and R. Becks

2009 Murex dye production at Troia: assessment of archaeomalacological data from old and new excavations. Studia Troica 18: 87-103.

Carannante, A.

2014 Archaeomalacology and purple-dye: state of the art and new prospects of research. In J.J. Cantillo, D. Bernal and J. Ramos (eds.), Moluscos y Púrpura en Contextos Arqueológicos AtlánticoMediterráneos: Nuevos Datos y Reflexiones en Clave de Proceso Histórico, 273-82. Cádiz: Universidad de Cádiz.

Cardon, D.

2007 Natural Dyes: Sources, Tradition, Technology and Science. London: Archetype.

Carrasco, M.S.

2004 Estudio malacológico de las especies vinculadas a la explotación de la púrpura halladas en Carthago Nova (2a mitad del s. III a.C.-I d.C.). In C. Alfaro, J.P. Wild and B. Costa (eds.), Purpureae Vestes. Textiles y Tintes del Mediterráneo en Época Romana, 211-13. València: Universitat de València.

Cazzella, A., C. Minniti, M. Moscoloni and G. Rechia

2005 L'insediamento dell'Età del Bronzo di Coppa Nevigata (Foggia) e la più antica attestazione della produzione della porpora in Italia. Preistoria Alpina 1(40): 177-82.

Celestino, S., and J. Jiménez (eds.)

2005 El periodo Orientalizante. Madrid: Consejo Superior de Investigaciones Científicas.

Cooksey, C.

2017 Recent advances in the understanding of the chemistry of Tyrian purple production from Mediterranean molluscs. In H. Landenius Enegren and F. Meo (eds.), Treasures from the Sea: Sea Silk and Shellfish Purple Dye in Antiquity, 73-78. Oxford: Oxbow Books.

Costa, B.

2011 Mapa de los yacimientos purpurígenos de la Islas Pitiusas. Resultados de la prospecciones costeras realizadas en Ibiza y Formentera (20052007). In C. Alfaro, J.-P. Brun, P. Borgard and R. Pierobon Benoit (eds.), Purpureae Vestes III. Textiles y Tintes en la Ciudad Antigua, 261-68. València: Universitat de València.

Cruz-Berrocal, M., L. García and A. Gilman (eds.)

2013 The Prehistory of Iberia: Debating Early Social Stratification and the State. New York and 
London: Routledge. https://doi.org/10.4324/ 9780203072035

Del Freo, M., M.-L. Nosch and F. Rougemont

2010 The terminology of textiles in the Linear B tablets, including some considerations on Linear A logograms and abbreviations. In C. Michel and M.-L.B. Nosch (eds.), Textile Terminologies in the Ancient Near East and the Mediterranean Area from the 3rd to the 1st Millennia BC, 33887. Oxford: Oxbow Books.

Domínguez-Bella, S., R.J. March, J.M. Gener and J. Martínez

2011 Análisis de restos orgánicos de la tumba púnica de la Casa del Obispo, Cádiz. Reconstruyendo la memoria fenicia en el occidente del Mediterráneo. In J.C. Domínguez (ed.), Gadir y el Círculo del Estrecho Revisados, 307-19. Cádiz: Servicio de Publicaciones de la Universidad de Cádiz.

Feldman, M.H.

2014 Communities of Style: Portable Luxury Arts, Identity, and Collective Memory in the Iron Age Levant. Chicago: University of Chicago Press. https://doi.org/10.7208/chicago/9780226164427.001.0001

Fernández, L.E., J. Suárez, J. Mayorga, A. Rambla, I. Navarro, A. Arancibia and M.M. Escalante

1997 Un poblado indígena del siglo VIII a.C. en la Bahía De Málaga. La intervención de urgencia en la Plaza de San Pablo. In M.E. Aubet (ed.), Los Fenicios en Málaga, 215-51. Málaga: Servicio de Publicaciones de la Universidad de Málaga.

Fischer, P.M., and T. Bürge

2016 The new Swedish Cyprus expedition 2015: excavations at Hala Sultan Tekke. Opuscula 9: 33-58.

Gener, J.M., M.A. Navarro, J.M. Pajuelo, M. Torres and E. López

2014 Arquitectura y urbanismo de la Gadir fenicia: el yacimiento del 'Teatro Cómico' de Cádiz. In M. Botto (ed.), Los fenicios en la Bahía de Cádiz. Nuevas Investigaciones, 14-50. Rome: Fabrizio Serra.

Gleba, M.

2017 Tracing textile cultures of Italy and Greece in the early first millennium BC. Antiquity 91(359): 205-22. https://doi.org/10.15184/agy. 2017.144
Gleba, M., A. Mandolesi and M.R. Lucidi

2017b Textiles from Tomba dell'Aryballos Sospeso, Tarquinia. Origini 40: 29-44.

Gleba, M., and I. Vanden Berghe

2018 Textiles from Cumae Fondo Artìaco 104: structural and dye analyses. Jahrbuch des RömischGermanischen Zentralmuseums. (in press)

Gleba, M., I. Vanden Berghe and L. Cenciaioli

2017a Purple for the masses? Shellfish purple dyed textiles from the quarry workers' cemetery at Strozzacapponi (Perugia/Corciano), Italy. In H. Landenius Enegren and F. Meo (eds.), Treasures from the Sea: Sea Silk and Shellfish Purple Dye in Antiquity, 131-37. Oxford: Oxbow Books.

González, R., K. Schörle, F. Gayet and F. Réchin

2017 L'exploitation des resources maritimes de l'antiquité. Activités productives et organisation des territoires. Antibes, France: APDCA.

Guglielmino, R.

2013 I rapporti tra l'Italia e l'Egeo nell'età del bronzo e il ruolo di Roca. Alcuni spunti di riflessione. Annali della Scuola Normale Superiore di Pisa 5(2): 131-51.

Halstead, P., and V. Isaakidou

2011 Revolutionary secondary products: the development and significance of milking, animaltraction and wool-gathering in later prehistoric Europe and the Near East. In T.C. Wilkinson, E.S. Sherratt and J. Bennet (eds.), Interweaving Worlds: Systemic Interactions in Eurasia, 7th to the 1st Millennia BC, 61-76. Oxford: Oxbow Books.

Harris, $S$.

2018 From value to desirability: the allure of worldly things. World Archaeology 49: 681-99. https:// doi.org/10.1080/00438243.2017.1413416

Haubrichs, R.

2005 L'étude de la pourpre: histoire d’une couleur, chimie et experimentations. Preistoria Alpina 1(40): 133-66.

Hodos, T.

2017 Globalization: some basics. In T. Hodos (ed.), The Routledge Handbook of Archaeology and Globalization, 3-11. London and New York: Routledge.

Hopkins, $\mathrm{H}$.

2013 Reconstructing the dyeing industry of Pompeii through experimental archaeology: the challenges and rewards of a new approach. In $\mathrm{H}$. 
Hopkins (ed.), Ancient Textiles, Modern Science, 119-33. Oxford: Oxbow Books.

Houart, R.

2001 A Review of the Recent Mediterranean and Northeastern Atlantic Species of Muricidae. Rome: Evolver.

Hurst, H.R., and S. Owen (eds.)

2005 Ancient Colonizations: Analogy, Similarity and Difference. London: Duckworth.

Iacono, $\mathrm{F}$.

2013 Westernizing Aegean of LH IIIC. In M.E. Alberti and S. Sabatini (eds.), Exchange Networks and Local Transformations: Interaction and Local Change in Europe and the Mediterranean from the Bronze Age to the Iron Age, 60-79. Oxford: Oxbow Books.

James, M.A., N. Reifarth, A.J. Mukherjee, M.P. Crump, P.J. Gates, P. Sandor, F. Robertson, P. Pfälzner and R.P. Evershed

2009 High prestige royal purple dyed textiles from the Bronze Age royal tomb at Qatna, Syria. Antiquity 83(322): 1109-18. https://doi. org/10.1017/S0003598X00099397

Jensen, L.B., and F. Jensen

1965 The Story of Royal Purple. Champaign, Illinois: Garrard Press.

Kalaitzaki, A., A. Vafiadou, A. Frony, D.S. Reese, A. Drivaliari and I. Liritzis

2017 Po-pu-re: workshops, use and archaeometric analysis in pre-Roman central eastern Mediterranean. Mediterranean Archaeology and Archaeometry 17(1): 103-30.

Karali, L.

1999 Shells in Aegean Prehistory. British Archaeological Reports, International Series 761. Oxford: Archaeopress.

Karmon, N.

1999 Muricid shells of the Persian and Hellenistic periods. In I. Roll and O. Tal (eds.), ApolloniaArsuf, Final Report of the Excavations I. The Persian and Hellenistic Periods, 269-80. Tel Aviv: Tel Aviv University.

Karmon, N., and E. Spanier

1987 Archaeological evidence of the purple dye industry from Israel. In E. Spanier and M. Ron (eds.), The Royal Purple Dye and the Biblical Blue: Argaman and Tekhelet, 147-58. Jerusalem: Keter.
Koh, A., P. P. Betancourt, M. Nicole Pareja, T. M. Brogan and V. Apostolakou

2016 Organic residue analysis of pottery from the dye workshop at Alatsomouri-Pefka, Crete. Journal of Archaeological Science Reports 10: 536-38. https://doi.org/10.1016/j.jasrep.2014.12.005

Kolonas, L., C. Margariti, I. Skals, K. Sarri, I. Vanden Berghe and M.-L. Nosch

2017 Heirs from the loom: textiles from Stamna (Aitolia, Greece). A preliminary analysis. In M. Fotiadis, R. Laffineur, Y. Lolos and A. Vlachopoulos (eds.), Hesperos: The Aegean Seen from the West. Aegaeum 41: 533-42. Leuven: Peeters.

Koren, Z.C.

1995 High-performance liquid chromatographic analysis of an ancient Tyrian purple dyeing vat from Israel. Israel Journal of Chemistry 35: $117-$ 24. https://doi.org/10.1002/ijch.199500018

2005 The first optimal all-murex all-natural purple dyeing in the eastern Mediterranean in a millennium and a half. Dyes in History and Archaeology 20: $136-49$.

2013 New chemical insights into the ancient molluskan purple dyeing process. In R. Armitage and J.H. Burton (eds.), Archaeological Chemistry 8: 43-67. New York: Oxford University Press.

Lentini, A.

2009 Tra archeologia e archeometria, archeologia e paesaggio naturale: indagini archeobotaniche e fisico chimiche. In M.R. Belgiorno (ed.), Cipro all'Inizio dell'Età del Bronzo, 129-87. Rome: Gangemi.

Lo Porto, F.G.

1990 Porto Cesareo: l'insediamento protostorico di Scalo Di Furno. In F. D’Andria (ed.), Archeologia dei Messapi, 221-32. Bari, Italy: Edipuglia.

Macheboeuf, C.

2004 Pourpre et matières textiles: des ateliers aux Tabernae. In C. Alfaro, J.P. Wild and B. Costa (eds.), Purpureae Vestes. Textiles y Tintes del Mediterráneo en Época Romana, 137-43. València: Universitat de València.

Margariti, C., S. Protopapas, N. Allen and V. Vishnyakov 2013 Identification of purple dye from molluscs on an excavated textile by non-destructive analytical techniques. Dyes and Pigments 96: 774-80. https://doi.org/10.1016/j.dyepig.2012.11.003

Marzano, A.

2013 Harvesting the Sea: The Exploitation of Marine 
Resources in the Roman Mediterranean. Oxford: Oxford University Press. https://doi.org/10. 1093/acprof:oso/9780199675623.001.0001

Mazarakis-Ainan, A.

2012 The Kephala on Skiathos survey and excavation project. Online Report. Internet Edition: http://extras.ha.uth.gr/skiathos/en/season2012. asp.

McCorriston, J.

1997 The fibre revolution: textile extensification, alienation, and social stratification in ancient Mesopotamia. Current Anthropology 38: 51749. https://doi.org/10.1086/204643

McGovern, P.E., and R.H. Michel

1984 Royal purple and the pre-Phoenician dye industry of Lebanon. MASCA Journal 3: 67-70.

1990 Royal purple dye: the chemical reconstruction of the ancient Mediterranean industry. Accounts of Chemical Research 23: 152-58. https://doi. org/10.1021/ar00173a006

Mederos, A., and G. Escribano

2015 Oceanus Gaditanus. Oro, Púrpura y Pesca en el Litoral Atlántico Norteafricano y las Islas Canarias en Época Fenicia, Cartaginesa y Romana Republicana. Santa Cruz de Tenerife, Spain: Idea.

Meiers, F.

2017 Historical outline and chromatic properties of Purpura Rubra Tarentina and its potential identification with purple dye extracted from Bolinus brandaris. In H. Landenius Enegren and F. Meo (eds.), Treasures from the Sea: Sea Silk and Shellfish Purple Dye in Antiquity, 138-44. Oxford: Oxbow Books.

Metallinou, G., C. Moulherat and G. Spantidaki

2009 Archaeological textiles from Kerkyra. Arachne 3: 30-51.

Minniti, C.

2005 Shells at the Bronze Age settlement of Coppa Nevigata (Apulia, Italy). In D.E. Bar-Yosef (ed.), Archaeomalacology: Mollucs in Former Environments of Human Behaviour, 71-81. Oxford: Oxbow Books.

Moreno-García, J.C. (ed.)

2016 Dynamics of Production in the Ancient Near East. Oxford: Oxbow Books.

Morgan, C.

2001 Leukas, Philosophon Street. Chronique des fouilles en ligne. Internet Edition: http://chronique.efa.gr/index.php/fiches/voir/3410/.
2004 Salamis. Chronique des fouilles en ligne. Internet Edition: http://chronique.efa.gr/index.php/ fiches/voir/2638/

2007 Mitrou. Chronique des fouilles en ligne. Internet Edition: http://chronique.efa.gr/index.php/ fiches/voir/455/

2012 Kallithea. Chronique des fouilles en ligne. Internet Edition: http://chronique.efa.gr/index.php/ fiches/voir/4560/

2014 Lefkandi - Xeropolis. Chronique des Fouilles en Ligne. Internet Edition: http://chronique.efa.gr/ index.php/fiches/voir/4886/

Osborne, R., and B. Cunliffe (eds.)

2005 Mediterranean Urbanization, 800-600 BC. Oxford: Oxford University Press. https://doi. org $/ 10.5871 / \mathrm{bacad} / 9780197263259.001 .0001$

Pascual, J.L.

2014 Moluscos marinos y terrestres. In C. Mata (ed.), Fauna Ibérica. De lo real a lo imaginario (II), 103-107. València: Diputación de València.

Peyronel, L.

2008 Il ruolo della porpora nell'industria tessile SiroPalestinese de Bronze Tardo dell'età del Ferro. Le evidenze storico-archeologiche dei centri costieri. Rivista di Studi Fenici 34: 49-70.

Ramig, K., A. Islamova, J. Scalise, S. Karimi, O. Lavinda, C. Cooksey, A. Vasileiadou and I. Karapanagiotis

2017 The effect of light and dye composition on the color of dyeings with indigo, 6-bromoindigo, and 6,6'-dibromoindigo, components of Tyrian Purple. Structural Chemistry 28(5): 1-9. https:// doi.org/10.1007/s11224-017-0932-0

Reese, D.S.

1987 Palaikastro shells and bronze age purple-dye production in the Mediterranean basin. Annual of the British School at Athens 82: 201-206. https://doi.org/10.1017/S0068245400020438

2000 Iron Age shell purple-dye production in the Aegean. In J.W. Shaw and M.C. Shaw (eds.), Kommos IV. The Greek Sanctuary, 643-47. Princeton, New Jersey: Princeton University Press.

2005 Whale bones and shell purple-dye at Motya (western Sicily, Italy). Oxford Journal of Archaeology 24: 107-14. https://doi.org/10.1111/ j.1468-0092.2005.00227.x

2006 The LH IIIC marine invertebrates from Lefkandi. In R.D.G. Evely (ed.), Lefkandi IV. The Bronze Age. The Late Helladic IIIC Settlement 
at Xeropolis, 20-29. London: British School at Athens.

2010 Shells from Sarepta (Lebanon) and east Mediterranean purple-dye production. Mediterranean Archaeology and Archaeometry 10(1): 113-41.

Reifarth, N., and R. Drewello

2011 Textile Spuren in der Königsgruft. Vorbericht zu ersten Ergebnissen und dem Potential zukünftiger Forschungen. In P. Pfälzner (ed.), Interdisziplinäre Studien zur Königsgruft von Qatna, 469-82. Wiesbaden: Harrassowitz.

Riva, C.

2010 The Urbanisation of Etruria: Funerary Practices and Social Change, 700-600 BC. Cambridge: Cambridge University Press.

Ruscillo, D.

2005 Reconstructing murex royal purple and biblical blue in the Aegean. In D. Bar-Yosef Mayer (ed.), Archaeomalacology: Molluscs in Former Environments of Human Behaviour, 99-106. Oxford: Oxbow Books.

2006 Faunal remains from the civic buildings at Kommos. In J. Shaw and M. Shaw (eds.), Kommos V. The Monumental Minoan Buildings at Kommos, 803-804. Princeton, New Jersey: Princeton University Press.

Sanmartí, J.

2015 Long-term social change in Iron Age northern Iberia (ca. 700-200 вс). In A.B. Knapp and P. van Dommelen (eds.), The Cambridge Prehistory of the Bronze and Iron Age Mediterranean, 45470. New York: Cambridge University Press.

Schaeffer, C.F.A.

1951 Une industrie d'Ugarit, la pourpre. Annales Archéologiques de Syrie 1-2: 188-92.

Schubart, H., H.G. Niemeyer and M. Pellicer

1969 Toscanos: la factoría paleopunica en la desembocadura del río de Vélez. Excavaciones de 1964. Madrid: Ministerio de Educación y Ciencia.

Seton-Williams, M.V.

1967 The excavations at Tell Rifa'at, 1964. Second preliminary report. Annales Archéologiques Arabes Syriennes 17: 69-72. https://doi. org/10.2307/4199819

Sherratt, E.S.

2000 Circulation of metals and the end of the Bronze Age in the Eastern Mediterranean. In C.F.E. Pare (ed.), Metals Make the World Go Round: The
Supply and Circulation of Metals in Bronze Age Europe, 82-98. Oxford: Oxbow Books.

Singer, I.

2008 Purple-dyers in Lazpa. In B.J. Collins, M.R. Bachvarova and I. Rutherford (eds.), Anatolian Interfaces: Hittites, Greeks, and their Neighbours, 21-45. Oxford: Oxbow Books.

Soffer, O., J.M. Adovasio and D.C. Hyland

2000 The 'Venus' figurines: textiles, basketry, gender, and status in the Upper Paleolithic. Current Anthropology 41: 511-37. https://doi.org/10. $1086 / 317381$

Soriga, E.

2017 Mari(ne) purple: western textile technology in Middle Bronze Age Syria. In H. Landenius Enegren and F. Meo (eds.), Treasures from the Sea: Sea Silk and Shellfish Purple Dye in Antiquity, 79-95. Oxford: Oxbow Books.

Spanier, E.

1986 Cannibalism in muricid snails as a possible explanation for archaeological findings. Journal of Archaeological Science 13: 463-68. https://doi.

Spantidaki, S. org/10.1016/0305-4403(86)90015-4

2016 Textile Production in Classical Athens. Oxford: Oxbow Books.

Stern, E.

1978 Excavations at Tel Mevorakh (1973-1976) I. From the Iron Age to the Roman Period. Jerusalem: Hebrew University.

1994 Dor-Ruler of the Seas. Jerusalem: Israel Exploration Society.

Stieglitz, R.R.

1994 The Minoan origin of Tyrian purple. The Biblical Archaeologist 57(1): 46-54. https://doi.org/ $10.2307 / 3210395$

Susmann, N.M.

2015 Preliminary approaches for the identification and classification of Mediterranean Murex dye production sites. Ancient Textile Review 57: 89-100.

Tonc, A., and I. Radman-Livaja

2018 Protohistoric dye production on the eastern Adriatic? In M. Gleba, M.S. Busana and F. Meo (eds.), Purpureae Vestes VI. Textiles and Dyes in the Mediterranean Economy and Society. València: Universitat de València. (in press)

Tsetskhladze, G.R. (ed.)

2006 Greek Colonisation: An Account of Greek Colonies 


\section{Marin-Aguilera et al.}

and Other Settlements Overseas I. Leiden: Brill.

Uerpmann, M.

1972 Archäologische Auswertung der Meeresmolluskenreste aus der westphönizischen Faktorei von Toscanos. Madrider Mitteilungen 13: 165-67.

Veropoulidou, R.

2013 Sissi: the shell assemblages. In J. Driessen and Q. Letesson (eds.), Excavations at Sissi III. Preliminary Report on the 2011 Campaign, 185200. Louvain: Presses Universitaires de Louvain. Veropoulidou, R., S. Andreou, and K. Kotsakis

2008 Small scale purple-dye production in the Bronze Age of northern Greece: the evidence from the Thessaloniki Toumba. In C. Alfaro and L. Karali (eds.), Purpureae Vestes II. Vestidos, Textiles y Tintes. Estudios Sobre la Producción de Bienes de Consumo en la Antigüedad, 171-80. València: Universitat de València.

Voutsaki, S., and J. Killen (eds.)

2001 Economy and Politics in the Mycenaean Palace States. Cambridge Philological Society, Supplementary Volume 27. Cambridge: Cambridge Philological Society.

Wilson, A.I.

2004 Archaeological evidence for textile production and dyeing in Roman North Africa. In C.
Alfaro, J.P. Wild and B. Costa (eds.), Purpureae Vestes. Textiles y Tintes del Mediterráneo en Época Romana, 155-64. València: Universitat de València.

Wilson, A.I., P. Bennett, A.M. Buzaian, V. Fell, K. Göransson, C. Green, C. Hall, R. Helm, A. Kattenberg, K. Swift and E. Zimi

2001 Euesperides (Benghazi): preliminary report on the Spring 2001 season. Libyan Studies 32: 155-77. https://doi.org/10.1017/S0263718900005835

Wouters, J., I. Vanden Berghe, G. Richard, R. Breniaux and D. Cardon

2008 Dye analysis of selected textiles from three Roman sites in the eastern desert of Egypt: a hypothesis on the dyeing technology in Roman and Coptic Egypt. Dyes in History and Archaeology 21: 1-16.

Zaouali, J.

1994 Marine and land molluscs. In H.R. Hurst (ed.), Excavation at Carthage, 320-24. Oxford: Oxford University Press.

Zarmakoupi, M.

2013 The Quartier du Stade on late Hellenistic Delos: a case study of rapid urbanization (fieldwork seasons 2009-2010). ISAW Papers 6. Internet Edition: http://dlib.nyu.edu/awdl/isaw/isawpapers/6/ 